\title{
Reviewing the Role of Outdoor Lighting in Achieving Sustainable Development Goals
}

\author{
Pedro Tavares ${ }^{1, *}$, Dmitrii Ingi ${ }^{1}$, Luiz Araújo ${ }^{2}$ (D), Paulo Pinho ${ }^{1}$ and Pramod Bhusal ${ }^{1,3,(D)}$ \\ 1 Department of Electrical Engineering and Automation, Aalto University, 02150 Espoo, Finland; \\ dmitrii.ingi@aalto.fi (D.I.); paulo.pinho@aalto.fi (P.P.); pramod.bhusal@aalto.fi (P.B.) \\ 2 Department of Electrical Engineering, Federal University of Juiz de Fora, Juiz de Fora 36036-900, Brazil; \\ luiz.eduardo2016@engenharia.uffi.br \\ 3 Department of Optometry, Radiography and Lighting Design, University of South-Eastern Norway, \\ 3603 Kongsberg, Norway \\ * Correspondence: pedro.laguardiatavares@aalto.fi; Tel.: +358-503263688
}

Citation: Tavares, P.; Ingi, D.; Araújo L.; Pinho, P.; Bhusal, P. Reviewing the Role of Outdoor Lighting in Achieving Sustainable Development Goals. Sustainability 2021, 13, 12657. https://doi.org/10.3390/su132212657

Academic Editor: Aris Tsangrassoulis

Received: 19 September 2021

Accepted: 10 November 2021

Published: 16 November 2021

Publisher's Note: MDPI stays neutral with regard to jurisdictional claims in published maps and institutional affiliations.

Copyright: (c) 2020 by the authors. Licensee MDPI, Basel, Switzerland. This article is an open access article distributed under the terms and conditions of the Creative Commons Attribution (CC BY) license (https:// creativecommons.org/licenses/by/ $4.0 /)$

\begin{abstract}
The Sustainable Development Goals (SDGs) aim at providing a healthier planet for present and future generations. At the most recent SDG summit held in 2019, Member States recognized that the achievements accomplished to date have been insufficient to achieve this mission. This paper presents a comprehensive literature review of 227 documents contextualizing outdoor lighting with SDGs, showing its potential to resolve some existing issues related to the SDG targets. From a list of 17 goals, six SDGs were identified to have relevant synergies with outdoor lighting in smart cities, including SDG 3 (Good health and well-being), SDG 11 (Sustainable cities and communities), SDG 14 (Life below water) and SDG 15 (Life on land). This review also links efficient lighting roles partially with SDG 7 (Affordable and clean energy) and SDG 13 (Climate action) through Target 7.3 and Target 13.2, respectively. This paper identifies outdoor lighting as a vector directly impacting 16 of the 50 targets in the six SDGs involved. Each section in this review discusses the main aspects of outdoor lighting by a human-centric, energy efficiency and environmental impacts. Each aspect addresses the most recent studies contributing to lighting solutions in the literature, helping us to understand the positive and negative impacts of artificial lighting on living beings. In addition, the work summarizes the proposed solutions and results tackling specific topics impacting SDG demands.
\end{abstract}

Keywords: outdoor lighting; light-emitting diode; smart cities; sustainable development goals; well-being; human-centric lighting; integrative lighting; efficiency; sustainability; light pollution

\section{Introduction}

Living beings have an intrinsic relationship with natural light, strengthened along the evolution of life on Earth. The dynamic of photoperiodism shaped organisms' behaviors and capability to survive [1]. Most organisms either directly or indirectly depend on the sunlight to survive [2], except for specific communities living in deep sea hydrothermal vents ecosystems [3]. This relation points to the inherent impact that light can inflict on living beings. Analogously, this impact can be triggered by artificial light, resulting in positive or negative effects depending on the organism and features of the light (intensity, quality and exposure duration).

In humans, sight is generally the most preferable and recruited sense to perceive and interact with the surroundings [4]. The trends in urban dynamic rely significantly on sight perception of citizens to perform daily activities [5]. In this context, it is possible to affirm that the use of artificial light at night has positively affected the quality of human life associated with an increase of comfort and safety, which explains its omnipresence around us. Currently, artificial lighting is responsible for the expansion of lit outdoor areas at a rate of $2.2 \%$ yearly [6]. This environment modification through the amount and spectrum of light also triggers undesirable disruption for humans and other living beings. 
In addition to the growth in artificial lighting, the development of lighting technology and implementation of smart supportive structures were major factors for rupturing the paradigms of traditional lighting function. Smart lighting expands the discussion of broadness in lighting approaches as a key factor for enhancing the quality of life and supporting the future of smart cities [7]. The smart lighting market is expected to grow from $\$ 13.4$ billion in 2020 to $\$ 30.6$ billion in 2025 comprehending a broad variety of applications. In outdoor scenarios, smart lighting can be applied in highways and roadways, public spaces and architectural facades [8]. It is worth noting that the possibilities of modern technologies and controls, accompanied by comprehensive decision-making tools, provide the opportunity for city governance to make decisions for the optimal energy management without losing in stakeholders satisfaction $[9,10]$. In summary, smart outdoor lighting provides connectivity and safety support, aimed mainly at human-centric and energy savings approaches, which contributes to achieving many targets in 2030 Agenda.

The 2030 Agenda for Sustainable Development consists of a shared project, aiming at the peace and prosperity of the planet and humans. It was adopted by all United Nations Member States in 2015, including 193 countries. The aims of the Agenda are organized in 17 Sustainable Developments Goals (SDGs), where lighting aligns intrinsically with five of them: SDG 3 (Good health and well-being), SDG 7 (Affordable and clean energy), SDG 11 (Sustainable cities and communities), SDG 13 (Climate action), SDG 14 (Life below water) and SDG 15 (Life on land). To date, the SDGs project counts with 3106 events, 1307 publications, 5486 actions accomplished and 169 targets set [11], of which 16 of the latter are related to outdoor lighting. Nevertheless, to the best of the authors' knowledge, there are no studies yet revealing the interlinks between SDGs and possibilities of outdoor lighting systems, although they represent a wide range of features for supporting sustainable urban development.

Outdoor lighting is associated with SDG 3 mainly by a human-centric approach, involving psychological effects, visual and non-visual perception of light and safety. Three targets in SDG 3 were specifically recognized in outdoor lighting roles: 3.4 (Reduce mortality from non-communicable diseases and promote mental health), 3.6 (Reduce road injuries and deaths) and 3.9 (Reduce illnesses and deaths from hazardous chemicals and pollution). Target 3.4 is associated with psychological effects, visual and non-visual perception, whereas 3.6 is tackled by the safety aspects of lighting, offering traffic and accessibility support. Target 3.9 does not explicitly involve the lighting role. Nevertheless, the 2020 SDGs report still does not regard light pollution as an indicator of this target. The indicator only includes air, water and chemical pollution attributed to mortality rates. However, previous studies have shown the direct relation of light pollution to health threats [12].

In outdoor lighting, Target 7.3 is tackled by improving lighting efficiency with luminaire and control developments. The luminaire subsection specifies the improvement of efficiency due to its components, including lamp developments. In the control subsection, techniques and strategies are presented, showing the potential of energy savings by applying control of intensity, timing and spectrum in outdoor applications. In addition to sustainable actions, SDG 11 also aims to increase inclusiveness, resilience and safety for cities [13]. The inclusiveness aspect is related to Target 11.3 (Inclusive and sustainable urbanization) and 11.7 (Provide access to safe and inclusive green and public spaces). Outdoor lighting makes urban environments more accessible and safer. Properly lit areas can mitigate accident rates, specifically between vulnerable users, including disabled and elderly population $[14,15]$. Safety oriented lighting issues related to traffic and crime can also be combated through lighting design and control systems [16-18]. Moreover, Target 11.6 (Reduce the environmental impacts of cities) highlights the importance of energy efficiency and light pollution concerns in order to develop more sustainable public lighting systems.

The expansions of lit outdoor areas over the years consequently increased light pollution. Not only humans but all organisms are affected through the high presence of artificial lighting nowadays [19-21]. The change in night natural environment contextualizes func- 
tions of outdoor lighting that directly impact four targets from SDG 14 (14.1, 14.2, 14.5 and 14.a) and SDG 15 (15.1, 15.5, 15.8 and 15.9).

The main contribution of this review is to find the synergies of outdoor lighting with Sustainable Development Goals, showing the relevance of lighting for a sustainable future. dUndoubtedly, carefully structured interlinks will reveal the significant potential of outdoor lighting systems in various vectors of sustainable development, and, consequently, draw attention to the potential of improved and thoughtful outdoor lighting solutions. To clarify this synergy, each section summarizes studies from the main aspects of outdoor lighting presenting the positive or negative impacts of it on 15 targets of the five SDGs related to lighting.

In order to investigate synergies between outdoor lighting aspects and targets from SDGs, a comprehensive literature review of 227 documents was carried out. The source materials were identified using several research databases, including Google Scholar, Scopus and Web of Science. Selected scientific papers were not limited by date and covered studies in laboratory situations, as well as field studies and reviews. However, articles were not included in the review if their relevance nowadays is mitigated, for instance, studies which consider the applications of incandescent lamps. It is worth noting that three general groups of outdoor lighting topics were identified through reading abstracts of preliminary selected articles. Each aspect of outdoor lighting was stratified in topics and respective subtopics, which further were used as search terms. Then SDGs were carefully compared with identified subtopics. The Figure 1 is a map showing the interlinks found with this review between outdoor lighting aspects, its subtopics and targets from SDGs. The targets related to outdoor lighting were listed on the right side and attached to its respective SDG. SDG 11 also included Target 7.3 (yellow according to the color of SDG 7) and Target 13.2 (dark green according to the color of SDG 13) as they fit properly in sustainable cities and energy efficiency contexts. As it was stated above, the main aspects of outdoor lighting were hierarchically divided into topics (second column from left to right) and sub-topics (third column). The text of the paper follows the same sequence displayed in Figure 1, with aspects of outdoor lighting divided by sections, whereas its topics on the second row are divided in sub-sections.

This paper is organized as follows. Section 2 approaches outdoor lighting in humancentric involvement with targets from SDG 3 and 11, regarding the relation between wellbeing and radiation perception in humans. Section 3 presents improvement of efficiency in outdoor lighting, impacting on targets 7.3, 11.6 and 13.2. Section 4 displays lighting environmental impacts, presenting issues and solutions in light pollution interlinked with targets of SDG 14 and 15. Finally, in Section 5, conclusions are drawn summarizing findings from the reviewed papers, adding considerations of the authors about challenges and roles of outdoor lighting to resolve SDGs targets.

\section{Human-Centric Lighting}

Human-centric Lighting (HCL), currently called Integrative Lighting (IL) [22], supports demands on human beings considering non-visible and visible effects of light [23]. These demands of lighting are thought to improve well-being and health. Well-being in outdoor lighting addresses visual comfort, safety and aesthetic of the environment. From a health context, outdoor lighting systems can be designed and controlled in order to mitigate its disruption effect on humans. This section organizes the human-centric aspects of four topics aiming to clarify the synergies between outdoor lighting and SDG targets. From this perspective, the first subsection resumes the psychological effects related to outdoor lighting. The second subsection is dedicated to show lighting aspects related to visual perception and responses. Following that, the third subsection covers non-visual perception of light and the fourth subsection reviews lighting to improve safety. 

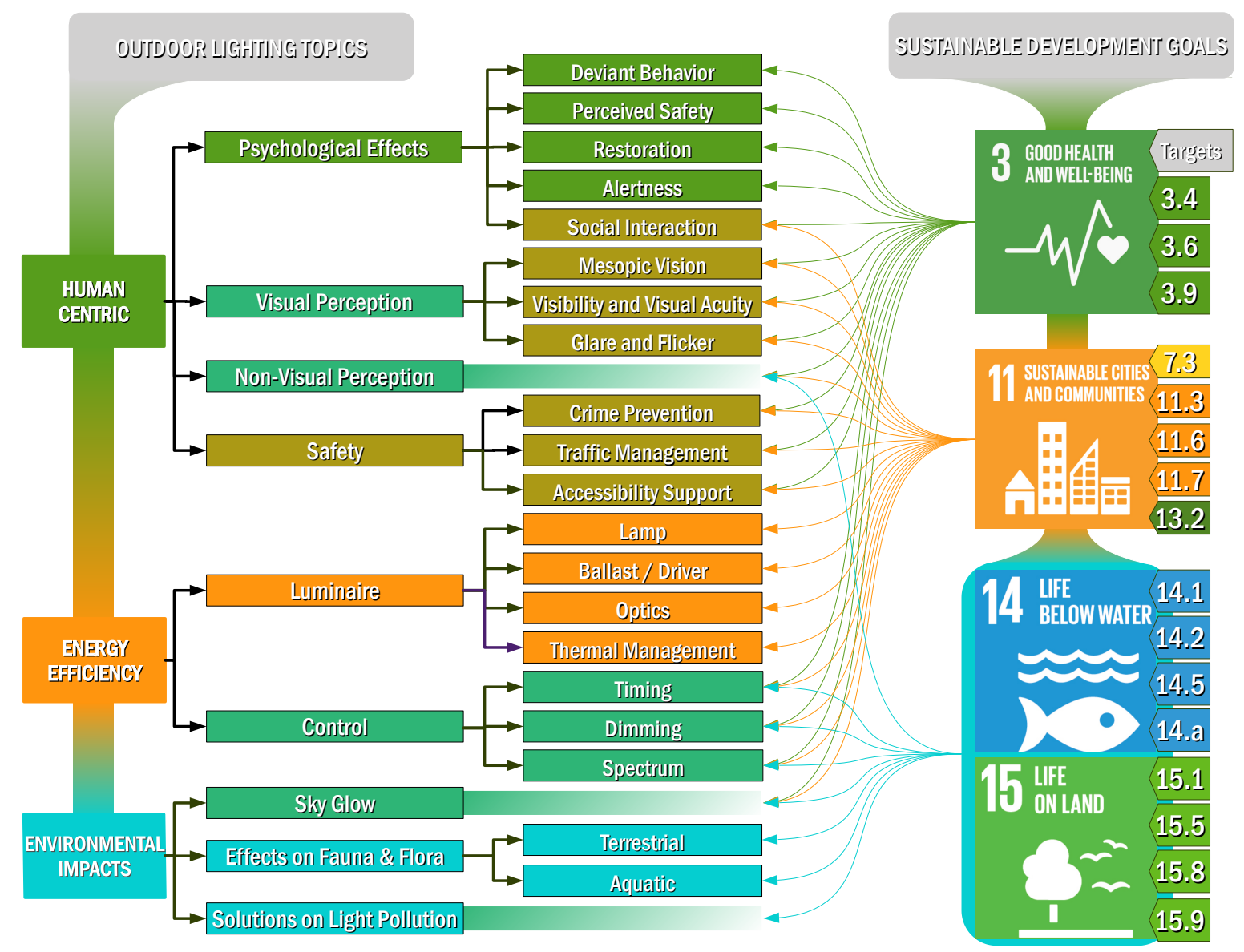

Figure 1. Map of outdoor lighting aspects and respective topics related with Sustainable Development Goals.

\subsection{Psychological Effects}

Nowadays, human-centric lighting is a major aspect of interest to influence mental states [24]. This influence of light in humans can impact positively and negatively through visual and non-visual perception of radiation. For example, adaptive lighting can be applied to induce desired feelings in users by changing its intensity and spectrum [25]. Some lighting systems have mood detection to identify different needs of stimulation required to enhance well-being [24], used also to enhance cognition [26]. Other studies approach lighting to promote a prosperous environment to treat psychological diseases, such as dementia [27], Alzheimer and depression [28].

Deviant behavior is an area in psychology characterized by practices that violates the social norms such as expression of violence to other people and animals, patrimony vandalism, sexual abuse and robbery $[29,30]$. These behaviors are encouraged in darker environments, where a sense of anonymity occurs due to the difficulty of facial recognition [30]. A study reinforced this, showing evidence of these behaviors, such as dishonesty actions associated with dark environments [31]. In contrast, a bright environment may induce self-regulation and self-awareness when performing impulsive actions [32]. It was also observed that a bright environment reinforces the ethical and altruism attitude of participants in an experiment, who were playing a game in different lighting environments [33]. In addition, behaviors, such as the violation of norms and the feeling of fear, are highly dependent on the context [34].

Perceived safety can be defined as an individual's subjective impression of security and lack of fear of becoming a victim going through a particular environment. Feeling of fear may restrict pedestrians to perform night time activities such as a simple walk and may also cause impacts to mental health, specifically in people with related traumatic experiences [35]. Evidence of association between fear and lighting environments is re- 
inforced by games and film strategies, which create an atmosphere to instigate fear with lighting aspects, such as flicker, low illuminance and red lighting [36]. Public lighting contributes to decreasing the feeling of fear, especially fear of crime. This contribution can be achieved by lighting escape routes and availing better facial recognition of pedestrians [37,38]. The study [30] presented by A.Haans and Y.A. de Kort found that people prefer having light in their own immediate surroundings rather than on the road that lies ahead. This could be explained, partially, by changes in prospect (having an overview), escape (perceived escape possibilities), and concealment (perceived hiding places for offenders). The results from another field study [39] showed that more uniform illuminance distributions are favourably perceived by people in terms of goodness of illumination, ability to see around and at a distance, and perception of safety. In addition, the findings of the research suggest that the spectral characteristics of lighting-emitting diode (LED) lighting systems can provide additional leverage over high pressure sodium (HPS) systems by providing greater scene brightness and perceptions of safety and security at lower power densities [40]. Moreover, the study [38] noticed that despite the fact that white light could lead to higher levels of light pollution, it seemed to make people feel safer. Overall, the current situation calls for more investigation of the precise relationship between feel of safety and the various characteristics of lighting environments, especially regarding the spectrum and duration aspects.

Outdoor lighting can also be designed to increase the restoration of pedestrians [41]. Restoration is the recovering process to restore human status of attention capability and psycho-physiological stress [42]. The presence of greenery remitting nature might be a factor to contribute to restoration. Elements such as vegetation can assist in restoring mental, emotional, and physical well-being [43]. Lighting can be applied to highlight these elements from nature to increase the restoration perceived in public spaces [41,44]. This strategy is reinforced by the biophilic hypothesis which explains the positive effects of nature elements on well-being originate from the strong biological bond between humans and the nature [45]. In addition to biophilic strategy, lighting intensity and quality are associated with conditions of stress and headache, which negatively impact the restoration process [38]. Nevertheless, the studies in the restoration field are limited. However, the acceptance of restoration effects of lighting is gradually increasing [43] and more efforts have been reported to clarify and validate findings [34].

Another psychological aspect is alertness. The alertness is highly desired in the context of productivity in outdoor workplaces and traffic safety regarding drivers awareness. Many studies evaluate the effect of light level and light spectrum on productivity responses $[24,25,46,47]$. Alertness stimulation depends on light intensity (high illuminated areas), time of exposure and spectrum. Regarding lighting spectrum, alertness effect is high in luminaires which emit more radiation in short wavelengths (bluish light) [48,49].

In traffic scenarios, outdoor lighting can improve safety by increasing alertness of drivers [50]. However, other studies show that a lighting stimulus of alertness can also be harmful when applied in the late day, interfering in hormone production and, consequently, health [51,52]. Therefore, the alertness stimulus has to be considered conciliating also the mitigation of undesired effects. Studies revealed also satisfactory stimulus response of alertness with long wavelengths $[53,54]$. With these studies it is plausible to conclude the possibility to conciliate alertness stimulus with low disruptive impact of lighting by avoiding short wavelengths in the spectrum.

Lighting may also provide a favorable environment for socialization, even though some studies do not identify conclusive results about it $[55,56]$. The synergy of lighting and socialization is complex due to high dependency from other factors that should be taken into account, such as local culture and activities performed. However, a bright environment with cool light can be associated with empathy stimulus [32], feeling that is associated with socialization actions. In contrast, a poorly lightened environment with warm light can lead to antisocial behaviors due to the concealment and anonymity $[30,38]$. 
From the previous review, it is possible to conclude that lighting has a major impact in human psychological aspects. Hence, lighting performs a key role to provide well-being addressed by SDG 3. However, the evaluation of lighting for well-being is highly subjective according to the user. Therefore, a consistent research has to use a mix of evaluation methods, combining results from field and experimental studies to provide a causal impact of lighting on well-being [47]. A consistent way to evaluate the psychological effects of light is based on survey forms. Surveys can be applied to establish a scope of criteria in order to match user requirements. For example, Koval et al. [57] based on Mehrabian and Russell psychological model and S-O-R (stimuli, organism, response) method to create a questionnaire in order to evaluate architectural lighting by user perspective.

\subsection{Visual Perception}

A good visual perception of the environment is crucial to guarantee the well-being in outdoor areas. The visual perception depends on its performance that, in turn, can be evaluated through visibility and visual acuity. Visibility is highly dependent on luminance levels of surrounding surfaces. Some examples that illustrate the importance and relation of visibility with outdoor lighting can be associated with identification of pedestrians by drivers [58] and identification of escape routes by pedestrians [37]. Visual acuity is related with the sharpness or the clarity of vision. Contrast and visual acuity have an intrinsic relation to improve visual conditions. For example, a study shows the improvement of visual performance increasing contrast in road scenarios by conciliating lighting level from the street luminaires and from car headlights [59]. Visual performance also depends on the light spectrum. At low lighting levels (mesopic vision), the short wavelengths have more lighting efficacy than the long wavelengths of the visible spectrum [60].

Another relevant parameter that compromises visibility is glare, impacting on visual comfort [61], visual performance [59], and safety [62], which affects directly well-being and health addressed in SDG 3 aims. Glare is caused by severe luminance contrasts that may bring discomfort or even reduce the ability to see details or objects [63]. Glare can generally be divided into two: disability and discomfort glare. The disability glare is wellestablished in literature whereas discomfort glare is not fully understood [34]. Discomfort glare depends on individual characteristics according to gender, age, fatigue status, light sensitivity, mood [64,65] and diseases, such as glaucoma [66]. Therefore the numerous variables to consider and the lack of standardized measurement makes evaluation of discomfort glare complex [67].

Even with these challenges, there are some methods to quantify glare. Unified Glare Rating (UGR) was the first method implemented to evaluate the multi-variable issue of discomfort glare [68]. More recently, new evaluations have been proposed considering a holistic perspective, combining quantitative and qualitative measurements of visibility loss with glare $[65,69]$. In addition to evaluation, solutions to mitigate glare can be found in the literature based on avoiding light to the line of sight to glare source with developments of collimators and reflectors of luminaires [70,71].

Although solutions to reduce glare already exist, the concerns of glare have been increasing. This is due to the growing popularity of architecture lighting applications disregarding light disruption. Zielinska-Dabkowska et al. [72] address the disturbances and safety threats that these lighting sources cause to urban users by investigating selfilluminated shops in Zurich. The investigation reported disruptions of stroboscopic effect and confusion caused in drivers, cyclists and pedestrians by these lighting sources [72].

Light flicker is another topic of concern regarding the visual quality of light. Flicker is the impression of brightness variation perceived due to fluctuation of luminance or spectral distribution [63]. This phenomenon directly impacts well-being and health in humans as it is associated with physical and psychological tiredness [73], as well as pathological effects [74]. Flicker is not only a visual perceived effect. Humans perceive flicker above Critical Fusion Frequency (CFF) up to $500 \mathrm{~Hz}$ [75]. This invisible flicker also impacts human health causing headache and eye strain [76]. Moreover, concerns on flicker involve not only 
static lighting sources, such as public lighting. Dynamic lighting sources such as marketing screens also highly impact civilians in urban areas [72]. Regarding this, it is important to consider conventional and dynamic lighting sources with flicker free in order to mitigate impacts reported to the health and well-being of users.

\subsection{Non-Visual Perception}

In addition to vision, eyes are also involved in non-visual functions, such as the entrainment of the circadian rhythm (CR). Circadian rhythm (CR) is an endogenous biologic process with an approximately 24-hours cycle [34]. It is subjacent to cell physiology in animals, plants, fungi, cyanobacteria and in some viral infections [77-79]. Artificial light can disrupt CR in humans $[80,81]$ and this disruption leads to risks in the health domains [82]. Some of these risks are related to cardiovascular $[83,84]$ and gastrointestinal complications [12,85], as well as metabolism disorders [86,87], hypertension, diabetes, stroke, dementia and depression [83]. In more recent studies, the disruptive effect of lighting in the CR is also suggested to be associated with the increase of susceptibility to viral infection, such as SARS-CoV-2 [88,89]. Hence, outdoor lighting can perform a central role to support the achievement of SDG 3 targets, maintaining a healthy environment at night.

Another impact of non-visual perception of light can be associated with melatonin production, which is regulated by a rhythm-generating system in the suprachiasmatic nucleus (SCN) [90,91]. Melatonin production occurs during the night [52] and influences important functions to our organism, such as anti-inflammatory and antioxidant activities [92]. Its secretion is dependent on age, light exposure that, in turn, is related to the circadian synchronization by means of intensity, spectrum and duration [91]. Regarding intensity of light, the minimum illuminance necessary to disrupt melatonin production at night in humans is $0.1 \mathrm{~lx}$ according to Grubisic et al. [51]. However, a study highlights that melatonin suppression level varies substantially across individuals. This study was conducted with 56 participants, the average to achieve $50 \%$ of melatonin suppression (ED50) was $25 \mathrm{~lx}$, with minimum ED50 of $6 \mathrm{~lx}$ for the highest sensitivity participant and $3501 \mathrm{x}$ for the lowest sensitivity one [93]. Regarding spectrum, it was discovered that circadian timing responds to short wavelengths [94]. Short wavelengths maximize the melatonin suppression with a full-width half-maximum sensitivity of 438 to $493 \mathrm{~nm}$ and the sensitivity peak at $477 \mathrm{~nm}$ [95]. Lighting impact on melatonin suppression depends also on the relation between light intensity and duration of exposure. In this context, Burgess et al. [96] suggest the quantification of melatonin disruption based in the Dim Light Melatonin Onset (DLMO). DLMO consists on the phase shift duration from the natural start of the daily melatonin production. Experiments performed with different photopic illuminances and duration of exposure showed considerable shifts on natural melatonin production cycle up to $109 \mathrm{~min}$ of DLMO [93]. The results of the previous studies reinforce the observations of rise in alertness at night in illuminated outdoor areas stated by Cajochen [97] and Plitnick et al. [54].

The American Medical Association (AMA) addresses the need for developing less disruptive lighting technologies without compromising visual performance. As a potential solution, AMA highlights the need of dimming and long wavelengths in the spectrum of lighting [81]. Other approaches to mitigate circadian disruption have been recommended such as avoiding the use of luminaires with spectral emission in short wavelengths of visible spectrum [95], the use of melanopic lux in lighting design [46] and application of light filters [98].

In general, non-visual lighting effects have not yet been studied precisely, because the topic is highly comprehensive and complicated. It is therefore recommended that special attention should be paid to the urban lighting environment, especially between about 7:00 p.m. and 9:00 a.m., when the effects of light on the human body are at their strongest [99]. 


\subsection{Safety}

One essential function of lighting is to provide safety, including preventing crime, supporting traffic management and providing accessibility. Lighting promotes surveillance of people, which studies have suggested can prevent crimes [16]. In addition, a welllit area decreases the feeling of anonymity in people, mitigating stimulus for deviant behavior [31]. However, a study indicates that the role of lighting in crime prevention more likely works via community pride and informal social control than through surveillance and deterrence [100]. In any case, empirical evidence reinforces the positive contribution of lighting to reduce crimes according to observation in different places [100-102].

The World Health Organization shows that approximately 1.35 million people die every year in traffic related accidents. Traffic accidents are recognized as a main health threat in urban settings, along with communicable and non-communicable diseases [103]. The target 3.6 of SDG 3 aimed to achieve a 50\% reduction in global deaths and injuries from road traffic accidents by 2020 . However, according to the 2020 SDGs report, death rates in road traffic accidents keep stagnating and, in some cases, even slightly increasing. Due to these results, Target 3.6 is one of six targets assigned as critical in the 2020 SDGs report [13]. Part of road accidents might be directly related to the poor lighting conditions in dark regions of rural and urban places as observed by Wanvik [17]. The International Commission on Illumination (CIE) 093-1992 report analysed 62 studies from 15 countries showing that in $85 \%$ of the cases lighting presents a positive impact in reduction of accidents [104]. More recently, a New Zealand study reinforces the lighting role to provide safety in traffic. The study indicates strong correlation between average luminance and vehicle crash ratios at nighttime [105]. In this context, lighting plays an important role as a safety structure in traffic as it may prevent deaths and injuries from road accidents [106]. The frequency and severity of road accidents are also connected with qualitative and quantitative lighting characteristics, but not only with presence of light. Some studies found a correlation between illuminance levels and car accidents [107].

It is important to highlight the increased presence of artificial lighting in outdoor spaces is not unanimously seen as a positive for safety in traffic. Some studies address some concerns about lighting impacting negatively performance of drivers by increasing fatigue and confidence [108], which in the last case can lead to high-speed and unsafe driving [109]. In an attempt to solve this issue, Visible Light Communication (VLC) can present feasible smart lighting solutions which support data communication in traffic aiming at improving safety such as collision avoidance and traffic flow efficiency $[110,111]$. Nevertheless, the impacts of qualitative aspects of light such as spatial distribution, spectrum and duration on road accidents are still barely investigated. Overall, the current situation calls for more investigation of the precise relationship between safety and the various characteristics of lighting environments provided by road lighting.

Lighting also improves safety from the pedestrian perspective. In Europe, around $22 \%$ of all traffic-related fatalities involve pedestrians [112]. In addition, the major part of collisions involving vehicles and pedestrians are in the darkness [113]. A study conducted in Florida showed that a proper street lighting environment reduced accidents from vehicles striking pedestrians by $42 \%$ at midblock and by $54 \%$ at intersections areas [114]. Pedestrian safety can also be approached by movement through places, involving navigation or handling urban obstacles, such as stairs and curbs. Therefore, it is essential that lighting provides proper visibility and contrast for obstacle distinctions, as well as recognition of different levels and irregularities on paths [115]. High frequency of accidents such as slips and falls are associated with places with poor lighting [116]. These accidents can cause serious injuries, specifically in more vulnerable users, such as children, the disabled and the elderly population $[14,15]$.

The results provided by Fotios and Uttley [117] suggests that a minimum photopic illuminance of 1.0 lux is sufficient light for pedestrians of all ages to safely detect (i.e., peripheral detection of a $10 \mathrm{~mm}$ obstacle $3.4 \mathrm{~m}$ ahead) and avoid trip hazards under any type of light source. Moreover, the findings of the subsequent research paper of S. Fotios 
et al. [118] found out that luminaire position (rear, overhead or front) have a significant effect on the detection of raised and lowered trip hazards. Regarding the elderly social group, the results of the study [119] found that both trial time and detection distance for older participants can be affected by rate of light levels. Shorter detection distance, greater number of fixations and longer fixation duration were found among older participants as opposed to young participants. Generally, it means that the vulnerability of elderly pedestrians can be reduced if better lighting is provided.

The world's population is ageing. In 2017, around $12.5 \%$ of the worldwide population was aged 60 or over [120]. Therefore, ageing is a relevant factor to consider in order to evaluate how lighting is perceived for this part of the population. For example, a study accomplished with 195 elderly participants revealed that visual impairment (vision loss) increased significantly with aging. The study measured visual activity in three different age groups. The results showed a $3.1 \%$ visual loss for $65-74$ years old, $11.6 \%$ for $75-84$ years old and $35.5 \%$ for $85+$ people [121]. Moreover, the elderly people are more susceptible to glare, as they generally face more difficulties in adaptation to drastic changes of lighting intensity and may take longer to interpret visual information [61,122,123]. Therefore, lighting uniformity, high illuminance and cool spectrum provides a safe accessibility for elderly users [124,125]. These characteristics promote inclusiveness in urban areas and, thus, collaborate with Target 11.3 and 11.7 of SDG 11.

In summary, lighting can also be used to increase the inclusiveness and attractiveness of public places for all users, not just for the elderly. In this context, the Geographic Information Systems (GISs) can be used as a tool to enable collaborative public participation in planning and improving lighting in urban areas. In a survey involving 162 topics, $6.8 \%$ of public opinions were suggestions related to improving public lighting for safety [126]. This result shows the importance of lighting and the relevance of the GIS to assist municipal management.

\section{Energy Efficient Lighting}

Lighting accounts for $16 \%$ of the world's electricity consumption [127]. It means that solutions to improve lighting efficiency have a substantial contribution to electricity savings and are paired with Target 7.3 of the SDG 7 (Double the improvement in energy efficiency). Improvements in energy efficiency also reduce energy-related carbon emissions contributing to the achievement of Target 11.6 of the SDG 11 (Reduce the environmental impacts of cities) and Target 13.2 (Integrate climate change measures into policy and planning). Energy efficiency in lighting involves luminaire elements and its lighting control. This section discusses various possibilities to improve energy efficiency in outdoor lighting.

\subsection{Luminaire Efficiency}

The main components responsible for overall efficiency of luminaires are the lamp, driver or ballast circuit, as well as thermal management and the optic system. The lamp can be evaluated by its efficiency (radiant flux per electric power demanded) or efficacy (luminous flux per electric power demanded). HPS are high-intensity discharge lamps that have been most widely used in street lighting for many years due to their high luminous efficacy and long lifetime [128]. However, in recent years, the luminous efficacy of Light Emitting Diodes has improved greatly. The luminous efficacy of the white LED package has increased from $69 \mathrm{~lm} / \mathrm{W}$ in 2006 to $175 \mathrm{~lm} / \mathrm{W}$ in 2019 and it is expected to reach $249 \mathrm{~lm} / \mathrm{W}$ by 2035 [129].

LED light sources use drivers and HPS use ballasts to convert AC power to suitable voltage and current needed for their operation. High-intensity discharge ballasts can reach an efficiency of 70-95\% [130]. In LED systems, the developments in integratedstage typologies and power electronic components collaborated for maximum efficiency improvements of LED drivers [131], achieving up to 92\% (2019) for outdoor lighting applications [129]. 
The light output of LEDs reduces when the junction temperature is increased. The drop in light output is represented by thermal efficiency droop. Currently, thermal efficiency droop in outdoor LEDs is 90\% (2019) [129], which means that the light output drops until $90 \%$ of its rated value for maximum operation temperatures. Thermal efficiency can be improved by heat dissipation using heat sink to cooler LEDs. High temperatures can influence degradation and failure of lighting mechanisms. Thus, proper dissipation is an essential topic in design to maximize lifetime and efficiency of the LED luminaires [132]. There are many studies regarding optimal efficacy using passive dissipation (heat sinks) [133,134], active dissipation (coolers) [134,135], thermal management design through LED package [136] and attachment interfaces [132].

Another element of luminaires is the optical system, which includes reflectors and lens to direct the light. HPS lamps emit light for 360 degrees (omnidirectional), requiring reflectors to direct a large portion of the emissions to the desired target area. Hence, HPS has a substantial reflection loss if compared with LEDs, which emit light for 180 degrees. The optical systems of outdoor LED lighting sums an efficiency of $87 \%$ in LED outdoor lighting (2019) [129].

Considering all main elements of the luminaire, the outdoor overall luminaire efficiency is $85 \%$ for HPS [130] and $72 \%$ (2019) for LEDs [129]. Besides the superior efficiency, HPS luminaires achieve a final photopic luminous flux efficacy of $85 \mathrm{~lm} / \mathrm{W}$ [137], against $126 \mathrm{~lm} / \mathrm{W}$ of LED outdoor luminaires [129]. This superiority of LEDs can be even higher if considering the mesopic vision [138]. Moreover, LED technologies are still in progress. By 2035, the goal is to achieve with drivers and optical efficiency of $95 \%$, overall luminaire efficiency of $86 \%$ and overall luminaire efficacy of $214 \mathrm{~lm} / \mathrm{W}$ for PC-LED outdoor luminaires [129].

\subsection{Lighting Control Effectiveness}

Modern lighting control is supported not only by luminaire technologies but also framed by automated sensing systems $[26,139]$, integration of lighting by internet of things [140] and big data access through GISs [126,141]. These tools account for a variety of smart lighting solutions. The smart lighting market is expected to grow from $\$ 13.4$ billion by 2020 to $\$ 30.6$ billion by 2025 , with a relevant part related to control applications regarding improvements on energy savings [8]. Outdoor lighting systems can save up to $84 \%$ of energy according to the control solution applied [10]. Lighting control can be divided in different strategies: time scheduling, group or zoning, occupancy, luminance and daylight adaptation, as well as personal control and demand response [142,143]. Pragmatically, all these controlling systems can be associated with changes in three lighting characteristics, including schedule operation (timing), intensity (dimming) and quality (spectrum).

Currently, there are numerous lighting solutions in the market related to timing and dimming control. Timing control is associated with programmable on-off status of the lamp. It is the most common control for effective lighting as it presents lower operation complexity than dimming and spectrum, allowing the application with overpass lamp technologies. Timing control can be applied by pre-programmed luminaires to turn off at a certain time of the night, attending local demand and improving outdoor lighting effectiveness. However, the turn off of lighting at night can negatively impact well-being by affecting visual perception of the environment and the feeling of safety. This issue can be partially resolved applying for sensors to detect presence. In this context, Sanchez and Cano-Ortega [140] list many pilots that use this automation of self-controlled luminaire units to conciliate energy savings with the demand of users. As the "on" state of the luminaire depends on the presence of the user, the system also requires control of other surrounding luminaires. Otherwise it can impact visibility, compromising the user's far sight of the environment. This issue can be solved with control of multiple lighting units (group control) to create a region of light around the user [143].

Lighting intensity is another aspect of control and can be achieved by dimming. Dimming light is a consistent way to increase energy savings of luminaires, decreasing its 
energy consumption according to the demanded levels. Dim lighting systems can adapt their brightness according to assessments in outdoor lighting, prioritizing requirements of the design stage including standards, energy efficiency and light pollution [144]. Dimming levels can also follow criteria of occupancy, daylight, personal preference and availability of the power system supply [143]. From the occupancy criteria, dimming of lighting levels can be correlated with traffic flow rates, offering proportional illuminance levels according to the number of users in the respective areas. An example of dimming application can be shown with a pilot applied in Rome. The operation of the pilot resulted in energy savings of $40 \%$, applying for dimming light in less demanding public areas, and 60\%, with automated dimming light on traffic [145]. Dimming can also be based on temperature operations to control precisely the flux of the luminaire. This technique provides relevant results when applied in outdoor luminaires, which are more exposed to weather conditions and, thus, relevant changes in luminous flux. This control technique was applied in a simulation with public lighting maintaining its luminous flux constant under variations of temperature extracted by Hungarian meteorological data. The simulation resulted in the increase of outdoor lighting efficiency in 10\% [146]. The efficiency results from this technique can be even higher considering wind models and places with lower atmospheric average temperatures than the Hungarian region.

The control of outdoor luminaires can conciliate energy savings with feasible costs without compromising demands of users. A retrofit project deployed in the University of Palermo campus (Italy) included timing and dimming operations in public LED lighting systems. The pilot achieved an energy saving of $84 \%$, equivalent to saving 163.2 tons of $\mathrm{CO}_{2}$. The study estimates that the system saved $280 \mathrm{MWh}$ due to timing control application plus $10 \mathrm{MWh}$ with selective dimming control. The project shows that timing and dimming can be financially feasible with a payback estimated in 3-4 years. Moreover, the project also shows that the control can be user friendly as the study reported a satisfaction of $80 \%$ related to safety and visibility perceived by users [10]. In addition to this study, the association of timing and dimming in lighting control are also applied in "tracking lighting" technique. This more sophisticated technique uses group control, synchronizing multiple lighting units to track movement of users and create a dynamic gradient of the lit area around them. Some pilots already implemented this technique for vehicles, pedestrians [140,147] and cyclists, achieving up to 77\% of energy savings [139]. It goes without saying that the choice of the technique and control strategies should be carefully considered for particular cities and sites. Notable that nowadays developed decision-making tools can be used by energy managers and local policy in order to optimize the energy retrofit plan of an existing public street lighting system throughout a wide urban area [148]. Integration of the timing and dimming strategies mentioned above into urban planning have a direct impact on accomplishing Target 13.2 .

The control of the spectrum can be achieved by dimming of independent channels of a luminaire, as well as controlling of white LED chips with different manufacturing combinations (e.g., red, green, blue (RGB)) [149]. The control of spectrum can use reference of correlated color temperature (CCT) or chromatic coordinates to achieve different objectives. The control of light intensity mixing cool and warm light can be applied to promote well-being and health basing on natural light [150] and circadian action factor (CAF) [151]. Moreover, red, green, blue, white (RGBW) LEDs can be applied to improve mesopic luminance and lighting efficacy in traffic by controlling the colors independently [151]. Although RGB LEDs generally are harder to find in outdoor lighting, they provide other assets such as faster responses of VLC communication in comparison with PC-LEDs [152]. This fact can contribute to raising the penetration of RGB LEDs in outdoor lighting in the future.

In summary, control of outdoor lighting systems presents significant results in energy savings and consequently an attractive payback time of investment. Despite these advantages, the control of outdoor lighting is not well presented in public spaces yet. For example, in the scenario of USA outdoor lighting, daylight control is presented in $39 \%$ of 
lighting units, 20\% includes timing control and less than $1 \%$ include other controls, such as dimming, occupancy sensing and integration of multiple units. In contrast, residential lighting presents $11 \%$ penetration of dimming systems whereas commercial establishments have $6 \%$ of lighting systems with occupancy sensors and $4 \%$ with timing control (2016) [137]. This comparison shows the lack of implementation in control solutions for outdoor lighting scenarios and its setback compared with what has been developed in other lighting sectors.

\section{Environmental Impacts of Light Pollution}

The advances in lighting technology have been followed by greater attention to its environmental impacts due to light pollution. Light pollution affects not only humans but also other living beings. According to the International Lighting Vocabulary, light pollution is a generic term that groups all adverse effects generated by artificial lighting [63]. In the literature, other terms are also applied to designate disruptive effects of lighting, such as Artificial Light at Night (ALAN) [153], Man-Made Sky Glow (MMSG) [154] and Obtrusive Lighting (OL) [155]. All three terms are related to anthropogenic changes of the natural light environment. However, while OL refers only to negative impacts in humans [63], ALAN can be refereed also to impacts in other living beings [153].

This section will approach light pollution from four angles, which are quantification, impacts, effects and mitigation solutions in order to cope with issues addressed by targets of SDGs 14 and 15.

\subsection{Light Pollution: Quantification and Astronomical Implications}

Lighting promotes life quality for humans in the sense of improving well-being and safety. These factors contributed consistently to lighting expansion in the world, increasing lighting demands in modern culture. This expansion can be displayed and quantified by the mapping of lit areas. Moreover, these lighting maps are extensively applied to assist evaluations of light pollution such as in Bennie et al. [156]. Lighting maps use data acquired through remote sensing of light emission by ground-based measurements, unmanned aerial systems (UAS) and satellites.

The ground-based measurements include equipment such as multi spectral cameras and spectrometers to measure incident and reflected radiation on surfaces [157]. The UAS or Unmanned Aerial Vehicles (UAV) have been popularized with Drones. They can be equipped with radiometric equipment to acquire aerial lighting data. The use of drones promotes not only high-resolution aerial lighting maps [158], but also luminance sensing from different viewing angles. In addition, UAV can also be applied as a "DroneGonio-Photometer" (DGPM) to build photometric polar diagrams of lighting intensity distribution, to quantify sky glow from large areas [159]. One of the aspects in which satellites differ from UAV and ground-based measurements is the operation at very high altitudes. This favors the covering of large scale areas to build lighting maps. On the other hand, satellite measurements have low to medium image resolution, with restricted angle of analyses, low controllability and higher costs of operation [160]. Other studies also specify constraints that might directly influence the estimation of light pollution by satellites. These constraints can lead to unreliable lighting measurements, underestimating the recent growth in light pollution. An example of miss quantification by satellites is the limitation to sense the increase of blue scattered light from cool white spectrum in outdoor lighting [160,161].

A valid option to quantify light pollution can be the merge of ground level measurements with aerial ones. In this context, some studies have identified a reasonable correlation for light imagery between ground and satellite measurements [162,163]. Another path to quantify light pollution can be found in analytical modelling methods of sky glow. Kocifaj et al. [164] relies on an effective retrieval method to quantify spill light, involving a large territory for real time computation. Moreover, Illumina is another model that calculates 
indirect and direct light pollution, considering diverse factors (aerosol types, observer position, pressure, humidity and others) [165].

Despite the limitations, the use of satellites is still a handful way to measure spill light reflected or directly emitted toward the sky, which contribute to the sky glow effect. The spill light compromises the contrast and the visibility of the stars causing aesthetic impacts for humans $[161,166]$ and might compromise navigation of animals that use the stars for orientation $[167,168]$. The sky glow was already addressed in 1980 by CIE 001 guideline for astronomical issues [169], which shows the subject is for long known. Even so, the concerns on the phenomenon have been on the rise due to the increase degradation of sky viewing conditions in the cities. This is in part due to the increase of lighting demand and lamps with spectral power distribution (SPD) rich in short wavelengths, resulted from replacement of conventional HPS with LED lighting in streets [161]. Another negative effect of sky glow remits to the well-being of people, who are prevented from recreation activity, such as seeing stars in urban places [166]. The visibility of Milky ways is recognized as an aesthetic value that has been decreasing [170]. The importance of it can be shown by Mitchell and Gallaway [171] estimation that tourists will spend $\$ 5.8$ billion over the next 10 years in the Colorado Plateau to spot stars. In addition, the blinding of stars might impacts directly also other organisms. Studies indicate that many animals use a celestial visual cue for orientation, including birds [167], seals [172] and even insects, such as the African ball-rolling dung beetles [168].

\subsection{Impacts on Aquatic Life}

Aquatic environments are essential in order to perform important human activities, such as recreation, tourism and fishing. The fishing industry has a substantial influence in socio-economic activities with 59.5 million people engaged in the sector. From 1961 to 2017 the average annual growth rate of fish consumption increased 3.1\%, which surpassed the population growth rate of $1.6 \%$ in the same period [173]. Beyond the importance for humans, aquatic ecosystems contribute for the attenuation of floods, recycling of nutrients, provision of habitat and water purification [174]. Oceans have the largest world ecosystem [13] and are the larger $\mathrm{CO}_{2}$ sink [175], absorbing between $23 \%$ to $31 \%$ of the carbon generated by humans yearly $[13,176]$. Hence, aquatic ecosystems perform essential functions to maintain natural balance dynamics of the planet Earth and lighting can impact on many of them.

The light pollution impacts on water should be taken as a crucial concern in order to preserve a sustainable world. The SDG 14 (Life below Water) addresses ten targets summarizing the concerns around the preservation of aquatic life. Among them, four targets can be linked with light pollution: Target 14.1 (Reduce marine pollution), 14.2 (Protect and restore ecosystems), 14.5 (Conserve coastal and marine areas) and 14.a (Increase scientific knowledge, research and technology for ocean health). Moreover, specifically Target 14.2 is one of the six critical targets in progress highlighted in the 2020 SDGs report, which emphasize the need for urgent actions to resolve it [13].

In humans, lighting also disrupts the circadian rhythm in other living beings. The CR is presented in all eukaryotes [177] and also in prokaryotes organisms [178]. A review presents a list of studies about circadian disruption on vertebrates, showing the impact of light through melatonin suppression including also aquatic species. In fishes, melatonin suppression was identified for 0.01-0.03 lx of lighting exposure [51], which is quite low in comparison with the recommended $1 \mathrm{~lx}$ of maximum vertical illuminance in low district brightness areas [155]. This shows the potential disturbance of lighting fishes living in coastal urban areas.

Following the classification by Davies et al. [179], the lighting impacts in aquatic life can be divided by changes in behavior, orientation, reproduction, recruitment, predation and communication. For marine ecosystems, the paper highlights impacts of light pollution in zooplankton migration, sessile invertebrate larvae settlement, aggregation of fish under pier lights and release timing of gametes by corals [179]. Since the publication of the 
paper in 2014, new studies have been accomplished regarding light pollution and its impacts in aquatic environments. One of these studies reinforces the rise of light pollution associated with the disruption of Diel Vertical Migration (DVM) in zooplanktons [180]. This undoubtedly generates substantial hampers to maintain marine ecosystems. Zooplanktons are part of the ecosystem chain base and feed on phytoplanktons, which are responsible for $80 \%$ of the oxygen production on Earth [181]. Corals are another base of the food chain in maritime ecosystems. A recent study in red coral reefs also identified potential adverse effects of artificial lighting in its habitat, including changes of photosynthetic efficacy [182].

The exposure to artificial light also interferes in camouflage and nocturnally changes of animals, leading to impacts on predation dynamics. The light pollution provides to predator species the advantage to better recognize their prey, extending the regime of predation along the night and lighting habitats that were naturally dark [179]. These lighting impacts can be observed by the aggregation of prey and predatory fish species [183], as well as the intensification of foraging behaviors later into the night [184].

In addition to predation, the visual recognition from different species is a major type of communication between them. However, Davies et al. [179] does not mention consistent evidence linking light pollution with communication changes. Nevertheless, some observations already address lighting impacts on communication through changing the attraction of mates. Recently, a study addressed impacts in camouflage and impaired visual communication due to changes in artificial lighting on underwater ecosystems, causing hybridization and loss of diversity in species [185].

Even with the increase in research relating to light pollution and its impacts on aquatic ecosystems, the issue remains hazily explored, with a lack of concise results addressing solutions to mitigate damages. This lack of results is partially reasonable due to the challenges of evaluating light pollution. Lighting can vary its impacts in different species, according to the spectrum and intensity levels. There are even studies pointing out that light pollution contributes positively for some species in the sense of increasing population. In this sense, a study showed that microbial communities exposed to ALAN can transform freshwater sediments in potential nocturnal carbon sinks [161]. Another study indicates that light pollution promotes more diversity in cyanobacterial families [186]. However, a recent article published in 2020 concludes that light pollution from coastal cities is likely having deleterious impacts on seafloor ecosystems and needs urgent studies to estimate the damage [187]. In summary, the discussion of the topic needs more attention as human activities are generally concentrated close to water [188], which contributes to increasing the light pollution impacts on these specific coastal areas.

\subsection{Impacts Terrestrial Life}

The SDG 15 focuses on the conservation of terrestrial and freshwater ecosystems, aiming for the sustainable exploration of these places. A recent information reported on SDG 15 shows a substantial decrease of biodiversity from species extinction rates from 0.82 in 1993 to 0.73 in 2020 and a forecast to reach 0.69 by 2030 [13]. The same report also claims that these alarming rates are mainly attributed to wildlife crimes and land degradation, where light pollution can also be included as an aggravating threat to biodiversity. In this context, light pollution can be associated with four targets of SDG 15, which are: 15.1 (conserve and restore terrestrial and freshwater ecosystems), 15.4 (conservation of mountain ecosystems), 15.5 (Protect biodiversity and natural habitats) and 15.9 (Integrate ecosystem and biodiversity in government planning). In addition, analogous to Target 14.2, Target 15.5 is also one of the six critical compromised targets in the 2020 SDGs report; thus, it is urgent to take actions for mitigation of anthropogenic interference on terrestrial ecosystems.

Evidence of the impact of light on non-visual perception is documented for many animals from terrestrial and freshwater environments. Based on the results obtained from a systematic literature review study, the minimum levels of melatonin suppression for birds, rodents and ungulates were detected at illuminances of $0.31 \mathrm{x}, 0.03 \mathrm{~lx}$ and $2.3 \mathrm{~lx}$, respectively. For amphibious and reptiles, there was not conclusive information about 
illuminance thresholds on melatonin suppression [51]. Despite this, light pollution impacts on amphibians and reptiles were also identified, such as changes in amphibian reproduction by affecting oviposition [189] and nocturnal activities [190]. In reptiles, light pollution has been linked with the increase of reproduction in Anolis lizards [191] and disorientation of hatchlings turtles to track the sea [192]. Furthermore, Perry et al. [193] extend the evaluation of disruptive lighting to other species, including frogs, lizards and snakes located in urban environments.

Light pollution also impacts invertebrates. Invertebrates are vital to diversity, ecosystem balance and have economic importance. For instance, bees are the core of the apiculture market and the main pollination insects in the world, contributing to the agriculture and biodiversity [194]. Therefore, the decline of the worldwide population of bees is a major concern. The drop in bee population is primarily due to the diminishing of natural habitat and flora [195]. Light pollution can be an aggravating factor. Studies already point to light pollution as a strong contributor to drive the decline of the insect population, impacting on pollination, pest control and nutrient cycling [196]. Apart from ecological lighting traps, light pollution affects many dynamics of insects, such as migration, growing, feeding, predation and reproductive behaviors $[197,198]$. More specifically, light pollution impacts behaviour of insects in migration by changes in phototaxis [199], in feeding by changes in herbivory [200], in predator and prey interactions by changing defense mechanisms [201], and reproduction by maladaptive responses to attract partners [202]. More studies in light pollution impacts with invertebrates are also reviewed for terrestrial and fresh waters in Underwood et al. [203].

The cross studies in light pollution are not restricted to impact relations between animals and humans. Plants rely on insects for reproduction dynamics, which means that the effects on insects also indirectly affect plants. A study highlights the artificial light impact on pollination success caused by a cascade effect between host plants, predators and prey [198]. Another recent study explored this cross evaluation by investigating the effects of artificial lighting in the interaction between plants and insects under a setup experiment with spectrum variation [204].

Plants also present disruption in their night cycle affected by light pollution [205-208]. In some cases, this disruption can be favorably used to schedule crops/gathering in floriculture [209] and horticulture [210]. The impact on plants will depend on the spectrum and the amount of irradiance incident on the leaves. In forests, where the light pollution is reduced, the amount of artificial radiation does not achieve relevant levels to directly trigger photosynthesis [211]. However, in urban areas the presence of artificial light is higher than in forests and light pollution impacts in plants are more remarkable [206,208]. Light disruption also can be observed in plant phenology indicators [208]. According to Singhal et al. [206], the impacts in night light pollution affects plants in physiological and behavioral functions, comprehending circadian clock, dark recovery from stress, metabolic fluxes and yield. Yield studies identified a $20 \%$ to $40 \%$ reduction in crops due to delays in the flowering of plants exposed to low radiance intensities through roadway light [212]. In some critical cases, lighting is even applied directly to illuminate plants for aesthetic purposes at night. This aesthetic approach increases even more the impacts on plants due to the high photosynthetic active radiation levels. Luminescent trees are an interesting option to solve this problem by conciliating aesthetics feature with the light source functionality in areas with low illuminance demand [213].

\subsection{Light Pollution Mitigation}

The conciliation between the lighting demands by humans and the mitigation of light pollution impacts is challenging. The increase of artificial lighting presence reflects only the attendance of anthropocentric needs. This situation is clearly depicted in relevant lighting standards such as the standards EN 13201-1-5 (Road lighting standards) [214], EN 12464-2 (Lighting of Outdoor Working Places) [215] and EN 12193 (Outdoor Sports lighting) [216]. However, currently there are no standards merely dedicated to light pollu- 
tion mitigation. Moreover, until very recently, existing standards and design guidelines only set the minimum required values of lighting parameters neglecting the importance of setting the maximum limits. This situation may not contribute to preserving a natural daily lighting regime and consequently to mitigate the related impacts on the ecosystem. Nevertheless, some guidelines concerning the mitigation of light pollution have been published. The CIE guide for Floodlighting (CIE 094:1993) [217] provides different levels considered in design by urban and rural areas, but without mentioning calculation and measurement methods. This is critical as floodlighting is a significant source of energy wastage and light pollution [144]. More recently an updated guideline specifically to obtrusive lighting, the CIE 150:2017 (second edition), was published [155]. The document includes recommendations on up limits for lighting parameters and other topics regarding light pollution such as design, installation, operation and maintenance. However, the document remains focused on human needs, photometric quantities (based on human eye sensitivity) and emphasizes effects on residences, transport users, sightseers and astronomical observations. Nevertheless, the CIE 150:2017 guideline establishes a differentiation of limits in illuminance according to area types by zone classification. The zones vary from 0 to 4 , with zone 0 comprehending natural dark environments, such as reserves, parks and optical observatories [155]. This zone classification presents a reasonable potential to conciliate the human interests and environmentally friendly lighting environments. In addition, these zones can be associated with lighting data mapping for further evaluation of impacts on specific areas. The information of mapped light pollution associated with local studies on ecological impacts can be incorporated as a sieve to complement the criteria for outdoor lighting design. In this context, lighting maps data can be applied to create personalized zones with specifically lighting demands and constraints. This method is essential when approaching urban environments critically susceptible to light pollution, for example coastal waters, parks and tangent forests $[153,179,218]$.

In summary, solutions for mitigating light pollution are widely based on control strategies. The control of dimming and timing of luminaires can be applied to decrease consistently the artificial light presence, providing only the essential lighting needed. Gaston et al. [205] displays a diagram indicating the pathways of ecosystem effects and contribution of lighting functions by timing and spectrum, omitting the importance of intensity control by dimming. Although dimming of street light was not found as a consistent diminish of sky glow [219], it is still an effective strategy to adequate light intensity according to user needs, avoiding surplus, thus, mitigating light pollution.

Spatial distribution can be also applied to mitigate light pollution, avoiding spill light by focusing only on aimed objects and areas that need to be lit. CIE 150:2017 presents a method for lighting design to quantify spill light through upward light ratio (ULR) and upward flux ratio (UFR) [155]. Another quantification is proposed through a "3D bounding box" methodology consisting in encasing structures to assess the amount of spill light generated from the respective light source. The bounding box is a method that can be assessed with lighting design software, such as Dialux and Relux [159]. The method is simple in order to popularize its application on a large scale and to support spill light quantification.

In general, the light spectrum involves a more complex evaluation to mitigate light pollution, partially because of the variety of responses in different organisms. Short wavelengths in the visible spectrum are an issue due to the Rayleigh effect, scattering more radiation by atmospheric particles than long wavelengths [98]. Moreover, insects in general are more sensitive to light perception at short wavelengths than long wavelengths of the spectrum $[197,220]$. It is also important to highlight that melatonin suppression under short wavelength exposure is higher than under long wavelengths, compromising the activities regulated by CRs in organisms such as vertebrates [51]. However, long wavelengths also impact organisms, for example causing disorientation of migratory birds. In order to address this problem, the use of green light sources in offshore areas has shown positive results [20]. 
Still about lighting spectrum topics, the majority of evidence on light disruption for living beings observed in this review is associated with radiation in short (e.g., blue) and long (e.g., red) wavelengths. In addition, the human eye is more sensitive to the middle range (e.g., green) of the visible spectrum, which is beneficial to improve the luminous efficacy of light sources [221]. According to these facts, it might be possible to infer that the use of green light is sufficient to conciliate human needs and mitigate light pollution. However, the favorable status of the green light is not absolute. In terrestrial ecosystems, there is evidence of disorientation in migration of European robin birds (Erithacus rubecula L.) caused by green light [222]. Moreover, the middle range of spectrum (e.g., green) presents a higher euphotic depth than the red and blue light [223], which contributes to increase the irradiance on water floor along offshore and urban coasts, where water is under higher presence of artificial lights. Figure 2 shows two structures that apply for aesthetic lighting in urban areas of Helsinki and Espoo cities (Finland), illustrating scenarios of potential living being disturbance. Figure 2a shows an intense red lighting incident on two facades of a building in Espoo, whereas Figure $2 b$ shows green light structures surrounding the Hanasaari power plant area, in the Helsinki coastal area.

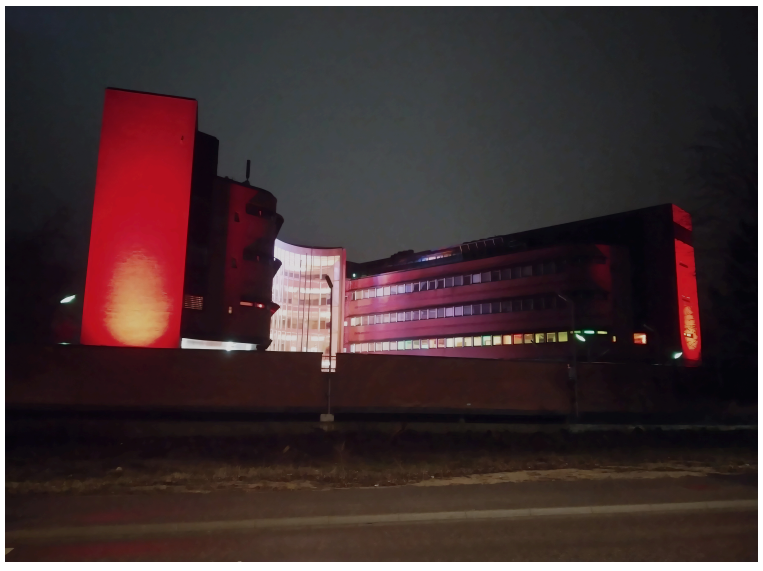

(a)

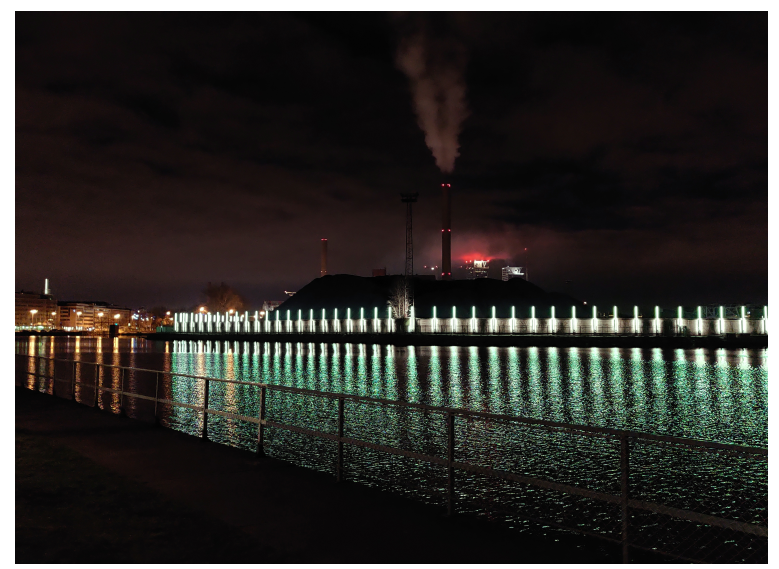

(b)

Figure 2. (a) Red light applied on facade of a building (b) Aesthetic structure of green light applied at urban coastal area.

Therefore, the impact of spectrum quality in light pollution highly varies due to the variability of negative (harmful), neutral (indifferent) or positive (favorable) responses among different living-beings in different environmental conditions. Thus, the zoning classification from CIE 150:2017 document can be adapted to a novel approach addressing also spectrum concerns for each area analysed in order to create a less disruptive lighting scenario for each specific environment. In this context, lighting can be designed considering critical needs and prioritizing threatened organisms.

The major part of the solutions to mitigate light pollution for living beings found in the literature focus on outdoor lighting Where the share of private lighting has been on the rise, aggravating light pollution. A recent experiment in Tucson (USA) only found a small reduction in radiance of the city from $18 \%$ to $13 \%$ by dimming the street lights [224]. According to Kuechly et al. [225], the contribution of spill light toward the sky from public areas comes not only from street lighting, but also from the shared contribution of vehicles headlights, advertising lighting and light from building facades, accounting all for $31.6 \%$ of the zenith directed light pollution in the city of Berlin. These findings call attention to the important contribution from private light sources to the light pollution in urban areas. Zielinska-Dabkowska and Schieck [226] point out the lack of legislation to address the indiscriminate application of digital billboards, whereas Bouroussis and Topalis also consider stadiums as another considerable source of spill lighting in cities [159]. Considering the current scenario, it is possible to conclude that only public initiatives to mitigate light pollution is insufficient to resolve the issue. 
An effective method to prevent light pollution should integrate the participation of local governments, industry, commerce, researchers and the general population. Swindall et al. [192] divide in three the strategies for changing human behavior in combating light pollution, which are: regulation, incentives and environmental education. The local government has to be assiduous by establishing regulations and normalizing lighting projects by mandatory actions based on research evidence and guidelines. Some actions have been taken towards calling attention of authorities to the potential of sustainable urban street lighting in an attempt to implement a green public procurement (GPP) by the European Union [227]. Similar actions can be established to instigate the industry and commerce sectors to follow more ecological friendly lighting designs, such as the incorporation of assessments of obtrusive lighting estimation proposed by Bouroussis and Topalis [159]. At last, from education strategy, the population has to get familiar with lighting as a recognized source of pollution. A suitable application of education strategy was applied promoting outreach information about light pollution impacts in sea turtles for the population settled in the impacted areas [192].

In most cases, studies miss conducting analysis by performing evaluations and drawing conclusions using quantities based on human eye spectral sensitivity curve to evaluate lighting impacts in organisms. This situation cannot be attributed not only to lack of knowledge on radiometric concepts, but also to limitations on equipment and literature data regarding eye sensitive curves for different organisms. Bennie et al. [207] recognize the demands to characterize the highly heterogeneous nature at night-time in order to predict lighting responses in plants, populations, communities and ecosystem levels. In the same line, Kvareninov et al. [208] highlights the importance of solid practical basis for better urban planning policies towards mitigation of light pollution effects on trees.

In conclusion, the mobilization of light pollution mitigation has to be based on breaking paradigms of the lighting use, implementing policy of minimum levels needed to perform target activities. Clearly it comprehends a complex trade off, specifically in urban areas, where the human interest conflicts more often with light pollution guidelines. The control of light through timing and dimming of lights can be applicable to mitigate effects of light pollution in general.

\section{Conclusions}

This review identified the roles of lighting directly affecting five SDGs. These five include 50 targets, of which 16 were recognized with direct involvement in outdoor lighting. The first section of the paper included human-centric lighting predominantly involving SDG 3, in order to promote well-being, health and safety conditions. The second section approached energy efficiency in lighting, impacting predominantly SDG 11 and two specific targets, one from SDG 7 and another one from SDG 13. At last, the paper presented the environmental impacts of lighting on living beings related to concerns addressed by targets from SDG 14 and 15.

The visual and non-visual perception of light triggers many responses in humans. These responses were linked in the review with psychological and physiological effects. In order to support Target 3.4, the understanding of the psychological effects in lighting is essential. It provides extra criteria to design outdoor lighting, increasing well-being values for users. The use of high illuminance levels and light sources with highly correlated color temperature (e.g., cool-white light) presented propitious results to combat deviant behavior and fear, improving alertness and possibly positively influencing social interaction. In contrast, low illuminance levels and low correlated color temperatures (e.g., warm-white light) showed a contribution to increasing restoration and to mitigating disruption of the CR. This review recognizes the disruption impact of light pollution on well-being and health, even though it is not mentioned as one source of pollution in Target 3.9 from SDG 3. The evidence found in the light pollution or disruption lighting context shows the importance of diminishing the presence of artificial light at nighttime in order to maintain the natural circadian clock and thus, health. 
The emergent growth of private lights in urban public areas also increased the concerns about well-being, health and safety in these areas. It is therefore urgent to regulate the use of these light sources and respective installations in order to decrease glare and confusion reported from pedestrians and drivers. Moreover, the design of street and road lighting consistently contributes to the safety of pedestrians and drivers by preventing crime, improving the accessibility of minority users and supporting traffic management. Solutions to mitigate traffic accidents are prioritized in Target 3.6 as it is one of six critical targets in the 2020 SDGs report that did not achieve the expected results. To resolve Target 3.6, the present review pointed out a gathering of studies showing that outdoor lighting solutions are crucial to mitigate traffic accidents by improving the visual performance of public areas.

Moreover, the inclusiveness aspect, which relates to Target 11.3 and 11.7, is strictly connected to outdoor lighting quality. When designing and integrating new lighting solutions, it is highly important to take into account the needs of vulnerable users, including disabled and elderly populations. In addition, proper lighting can also be used to increase the attractiveness of public spaces, encouraging people to live with a more active lifestyle during nocturnal time.

Energy efficiency is another area addressed in outdoor lighting that impacts SDGs. This review presented two subsections approaching lighting efficiency by equipment, involving luminaire components and lighting control, including techniques associated with timing, dimming and spectrum. It is clear and well known that, currently, LED technology dominates the current implementations of outdoor smart lighting due to its energy efficiency performance. Another energy efficiency aspect in outdoor lighting is through timing and dimming control. Pilots addressing outdoor lighting control reported energy savings of up to $84 \%$, equivalent to saving 163.2 tons of $\mathrm{CO}_{2}$. These expressive results facilitate the implementation of these control systems and strategies in outdoor lighting on a large scale, and, consequently, highlight the potential of a possible significant contribution to SDG 7 (Target 7.3), SDG 11 (Target 11.6) and SDG 13 (Target 13.2). However, the penetration of these control systems is still low. For example, in the USA, only $20 \%$ of the luminaires have timing control and less than $1 \%$ present dimmer control.

Dimming and timing can present trade-offs related to well-being issues. The decrease of lit areas is able to impact negatively in terms of reassurance, alertness and, mainly, safety. In contrast, less light impacts positively by mitigating circadian disruption and other effects related to light pollution. Sky glow has been reported as harmful for star observation, negatively impacting the astronomy and tourism sectors. Moreover, light pollution affects other living beings with higher impacts reported in urban areas. With the increase of artificial light presence in the world, the maintenance of natural ecosystems and its biodiversity became a key issue in lighting design. From the six critical targets highlighted in the 2020 SDGs report, two of them (14.2 and 15.5) are related to environmental aspects with lighting involvements (moreover, it can be associated with Targets 14.1, 14.5, 14a, 15.1, 15.8, 15.9 indirectly). The critical results from these two targets illustrate the urgent need to take action in order to mitigate light pollution. In this context, this review highlights a series of proposed actions tackling the light pollution in terrestrial and aquatic ecosystems, which are:

- $\quad$ Breaking paradigms in lighting design assuming minimum illuminance levels required and implement standardized maximum limits allowed;

- $\quad$ Generalize the use of outdoor lighting control by timing and dimming decreasing illuminance and lit areas;

- $\quad$ Optimizing lighting designs avoiding spill lighting;

- Adopting holistic lighting design including evaluation of light pollution impacts in local organisms affected;

- Confirm and consolidate results with greenish outdoor lighting;

- Enhancing light pollution detection and measurement by the use of sensing and complimentary computational models for simulations; 
- Promoting ecology education for civilians warning about light pollution impacts and promoting guideline actions to mitigate light pollution;

- Encouraging ecological friendly designs of lighting in commercial and industry sectors;

- Promote active governance participation in creating regulations and performing public lighting practices to mitigate light pollution.

To summarize, outdoor lighting is revealed as a powerful tool to support Sustainable Development Goals. With its professional, evidence-based design, the potential for a positive impact on various aspects of human life, as well as on the quality of the environment and energy efficiency levels is promising. It is worth noting that, during the work process, a shortage of scientific research and contradictory results were identified, especially in some areas of human-centric lighting (e.g., relationship between feel of safety, as well as safety aspects and the various characteristics of lighting environments, lighting impacts on restoration and socialization, non-visual lighting effects in the urban context). Moreover, it was found that the same outdoor spaces can hypothetically require simultaneously competing settings for supporting energy efficiency, environmental sustainability, light pollution and citizens' comfort. Nevertheless, it can be assumed that the development and integration of smart lighting systems, which allow the creation of dynamic, adaptive and intelligent lighting scenarios, may solve this problem. Such lighting systems provide the opportunity to establish a reasonable balance between the lighting needs of human beings and environmental sustainability and energy efficiency. This approach undoubtedly has the potential to enhance the beneficial effect for all selected SDGs. However, the studies, which investigate the short-term and long-term impacts of dynamic lighting on the abovementioned indicators, are also limited. The continuation of research in the identified areas will help to create guidelines that allow various lighting professionals, as well as energy managers and governance workers, to make outdoor lighting more beneficial for SDGs.

Author Contributions: P.T.: Investigation, Methodology, Project administration, Visualization, Writing-original draft/review; D.I.: Investigation, Writing-review and editing; L.A.: Investigation, Writing-original draft/review and editing; P.P.: Methodology, Supervision, Conceptualization, Writing—review and editing; P.B.: Funding acquisition, Methodology, Supervision, Writing-review and editing. All authors have read and agreed to the published version of the manuscript.

Funding: This research was funded by H2020 project "FINEST TWINS", grant number 856602.

Acknowledgments: The authors thank the technical support given by Technical Coordinator of Aalto University Vesa Korhonen, administrative support of Jorma Kyyrä and Emprapa Enthomology Researcher Adauto Maurício Tavares for technical contributions to the paper.

Conflicts of Interest: The authors declare no conflict of interest. The founders had no role in the design of the study; in the collection, analyses, or interpretation of data; in the writing of the manuscript, or in the decision to publish the results.

\section{References}

1. Ouyang, J.Q.; Davies, S.; Dominoni, D. Hormonally mediated effects of artificial light at night on behavior and fitness: Linking endocrine mechanisms with function. J. Exp. Biol. 2018, 221. [CrossRef]

2. Chapin, F.S.; Pamela Matson, H.M. Principles of Terrestrial Ecosystem Ecology; Springer: New York, NY, USA, 2002.

3. Fisher, C.R.; Takai, K.; Le Bris, N. Hydrothermal Vent Ecosystems. Oceanography 2007, 14-23. [CrossRef]

4. Gerrig, R.J.; Zimbardo, P.; Svartdal, F.; Brennen, T.; Donaldson, R.; Author, P. Psychology and Life, 20th ed.; Pearson: Boston, MA, USA, 2013; p. 85.

5. World Health Organization. World Report on Vision; World Health Organization: Geneva, Switzerland, 2019; p. 160. ISBN 9789241516570. Available online: https://apps.who.int/iris/handle/10665/328717 (accessed on 10 October 2019).

6. Kyba, C.C.M.; Kuester, T.; Sánchez de Miguel, A.; Baugh, K.; Jechow, A.; Hölker, F.; Bennie, J.; Elvidge, C.D.; Gaston, K.J.; Guanter, L. Artificially lit surface of Earth at night increasing in radiance and extent. Sci. Adv. 2017, 3. [CrossRef] [PubMed]

7. Karlicek, R.F. Smart lighting-Beyond simple illumination. In Proceedings of the 2012 IEEE Photonics Society Summer Topical Meeting Series, Seattle, WA, USA, 9-11 July 2012; pp. 147-148. [CrossRef]

8. MarketsandMarkets. Market Research Report SE 2506, Smart Lighting Market-Global Forecast To 2025; MarketsandMarkets: Dallas, TX, USA, 2020. 
9. Carli, R.; Dotoli, M.; Cianci, E. An optimization tool for energy efficiency of street lighting systems in smart cities. IFACPapersOnLine 2017, 50, 14460-14464. [CrossRef]

10. Beccali, M.; Bonomolo, M.; Brano, V.L.; Ciulla, G.; Di Dio, V.; Massaro, F.; Favuzza, S. Energy saving and user satisfaction for a new advanced public lighting system. Energy Convers. Manag. 2019, 195, 943-957. [CrossRef]

11. United Nations, The 17 Goals. Available online: https://sdgs.un.org/goals (accessed on 29 April 2021).

12. Bishehsari, F.; Levi, F.; Turek, F.W.; Keshavarzian, A. Circadian Rhythms in Gastrointestinal Health and Diseases. Gastroenterology 2016, 151, e1. [CrossRef]

13. United Nations. The Sustainable Development Goals Report 2020; United Nations: Rome, Italy, 2020; p. 66. ISBN 9789210049603. [CrossRef]

14. Congiu, T.; Sotgiu, G.; Castiglia, P.; Azara, A.; Piana, A.; Saderi, L.; Dettori, M. Built Environment Features and Pedestrian Accidents: An Italian Retrospective Study. Sustainability 2019, 11, 1064. [CrossRef]

15. Delbaere, K.; Close, J.C.; Heim, J.; Sachdev, P.S.; Brodaty, H.; Slavin, M.J.; Kochan, N.A.; Lord, S.R. A multifactorial approach to understanding fall risk in older people. J. Am. Geriatr. Soc. 2010, 58, 1679-1685. [CrossRef]

16. Welsh, B.C.; Farrington, D.P. Effects of Improved Street Lighting on Crime. Campbell Syst. Rev. 2008, 4, 1-51. [CrossRef]

17. Wanvik, P. Effects of road lighting: An analysis based on Dutch accident statistics 1987-2006. Accid. Anal. Prev. 2009, 41, 123-128. [CrossRef]

18. Doleac, J.L.; Sanders, N.J. Under the Cover of Darkness: How Ambient Light Influences Criminal Activity. Rev. Econ. Stat. 2015, 97, 1093-1103. [CrossRef]

19. Hopkins, G.R.; Gaston, K.J.; Visser, M.E.; Elgar, M.A.; Jones, T.M. Artificial light at night as a driver of evolution across urban-rural landscapes. Front. Ecol. Environ. 2018, 16, 472-479. [CrossRef]

20. Marquenie, J.M.; Wagner, J.; Stephenson, M.T.; Lucas, L. Green Lighting the Way: Managing Impacts from Offshore Platform Lighting on Migratory Birds. In Proceedings of the SPE International Conference on Health, Safety, and Environment, Long Beach, CA, USA, 19 March 2014. [CrossRef]

21. Hagen, O.; Santos, R.; Schlindwein, M.; Viviani, V. Artificial Night Lighting Reduces Firefly (Coleoptera: Lampyridae) Occurrence in Sorocaba, Brazil. Adv. Entomol. 2015, 3, 24-32. [CrossRef]

22. CIE. Position Statement on Non-Visual Effects of Light: Recommending Proper Light at the Proper Time; CIE: Hong Kong, China, 2019.

23. Houser, K.W.; Esposito, T. Human-Centric Lighting: Foundational Considerations and a Five-Step Design Process. Front. Neurol. 2021, 12, 25. [CrossRef] [PubMed]

24. Cupkova, D.; Kajati, E.; Mocnej, J.; Papcun, P.; Koziorek, J.; Zolotova, I. Intelligent human-centric lighting for mental wellbeing improvement. Int. J. Distrib. Sens. Netw. 2019, 15. [CrossRef]

25. Zhang, R.; Campanella, C.; Aristizabal, S.; Jamrozik, A.; Zhao, J.; Porter, P.; Ly, S.; Bauer, B.A. Impacts of Dynamic LED Lighting on the Well-Being and Experience of Office Occupants. Int. J. Environ. Res. Public Health 2020, 17, 7217. [CrossRef] [PubMed]

26. Roslyakova, S.V.; Chirimisina, D.A.; Lyubakova, Y.S. Possibilities to integrate wearable biomonitoring sensors into adaptive lighting systems. In IOP Conference Series: Materials Science and Engineering; IOP Publishing Ltd: Bristol, UK, 2020; Volume 944, p. 012029. [CrossRef]

27. Torrington, J.M.; Tregenza, P.R. Lighting for people with dementia. Light. Res. Technol. 2007, 39, 81-97. [CrossRef]

28. Figueiro, M.G.; Plitnick, B.A.; Lok, A.; Jones, G.E.; Higgins, P.; Hornick, T.R.; Rea, M.S. Tailored lighting intervention improves measures of sleep, depression, and agitation in persons with Alzheimer's disease and related dementia living in long-term care facilities. Clin. Interv. Aging 2014, 9, 1527-1537. [CrossRef]

29. Dinitz, S.; Dynes, R.R.; Clarke, A.C. Deviance: Studies in Definition, Management, and Treatment, 2nd ed.; Oxford University Press: New York, NY, USA, 1975.

30. Haans, A.; de Kort, Y.A. Light distribution in dynamic street lighting: Two experimental studies on its effects on perceived safety, prospect, concealment, and escape. J. Environ. Psychol. 2012, 32, 342-352. [CrossRef]

31. Zhong, C.B.; Bohns, V.K.; Gino, F. Good Lamps Are the Best Police: Darkness Increases Dishonesty and Self-Interested Behavior. Psychol. Sci. 2010, 21, 311-314. [CrossRef]

32. Steidle, A.; Werth, L. In the Spotlight: Brightness Increases Self-Awareness and Reflective Self-Regulation. J. Environ. Psychol. 2014, 39, 8-9. [CrossRef]

33. Chiou, W.B.; Cheng, Y.Y. In broad daylight, we trust in God! Brightness, the salience of morality, and ethical behavior. J. Environ. Psychol. 2013, 36, 37-42. [CrossRef]

34. Tähkämö, L.; Nikunen, H.; Bhusal, P. Outdoor Lighting Promoting Well-Being. Int. J. Inf. Technol. 2016, 4, 59-71.

35. Lorenc, T. Fear of crime and the environment: Systematic review of UK qualitative evidence. BMC Public Health 2013, 13. [CrossRef] [PubMed]

36. Graja, S.; Lopes, P.; Chanel, G. Impact of Visual and Sound Orchestration on physiological arousal and tension in a horror game. IEEE Trans. Games 2020, 1. [CrossRef]

37. Van Rijswijk, L.; Haans, A. Illuminating for Safety: Investigating the Role of Lighting Appraisals on the Perception of Safety in the Urban Environment. Environ. Behav. 2018, 50, 889-912. [CrossRef] [PubMed]

38. Peña-García, A.; Hurtado, A.; Aguilar-Luzón, M. Impact of public lighting on pedestrians' perception of safety and well-being. Saf. Sci. 2015, 78, 142-148. [CrossRef] 
39. Narendran, N.; Freyssinier, J.; Zhu, Y. Energy and user acceptability benefits of improved illuminance uniformity in parking lot illumination. Light. Res. Technol. 2016, 48, 789-809. [CrossRef]

40. Rea, M.; Bullough, J.; Brons, J. Parking lot lighting based upon predictions of scene brightness and personal safety. Light. Res. Technol. 2017, 49, 293-304. [CrossRef]

41. Nikunen, H.; Korpela, K.M. The effects of scene contents and focus of light on perceived restorativeness, fear and preference in nightscapes. J. Environ. Plan. Manag. 2012, 55, 465-466. [CrossRef]

42. Hartig, T.; Staats, H. Restorative environments. J. Environ. Psychol. 2003, 23. [CrossRef]

43. Menardo, E.; Brondino, M.; Hall, R.; Pasini, M. Restorativeness in Natural and Urban Environments: A Meta-Analysis. Psychol. Rep. 2021, 124, 417-437. [CrossRef]

44. Mitchell, R.; Popham, F. Effect of exposure to natural environment on health inequalities: An observational population study. Lancet 2008, 372, 1655-1660. [CrossRef]

45. Wilson, E.O. Biophilia and the conservation ethic. In Evolutionary Perspectives on Environmental Problems; Routledge: London, UK, 1984; pp. 250-258.

46. Safranek, S.; Collier, J.M.; Wilkerson, A.; Davis, R.G. Energy impact of human health and wellness lighting recommendations for office and classroom applications. Energy Build. 2020, 226, 110365. [CrossRef]

47. Silvester, J.; Konstantinou, E. Lighting, Well-Being and Work Performance: A Review of the Literature. Technical report; City University, London, UK, 2010.

48. Solt, J. Changing perspectives on daylight: Science, technology and culture. In Sponsored Supplement to Science/AAS; Science/AAAS Custom Publishing Office: Washington, DC, USA, 2017; Volume 358, pp. 1-45.

49. Vandewalle, G.; Maquet, P.; Dijk, D.J. Light as a modulator of cognitive brain function. Trends Cogn. Sci. 2009, 13, 429-438. [CrossRef]

50. Yannis, G.; Kondyli, A.; Mitzalis, N. Effect of lighting on frequency and severity of road accidents. Proc. Inst. Civ. Eng.-Transp. 2013, 166, 271-281. [CrossRef]

51. Grubisic, M.; Haim, A.; Bhusal, P.; Dominoni, D.M.; Gabriel, K.M.A.; Jechow, A.; Kupprat, F.; Lerner, A.; Marchant, P.; Riley, W.; et al. Light Pollution, Circadian Photoreception, and Melatonin in Vertebrates. Sustainability 2019, 11, 6400. [CrossRef]

52. Lucas, R.; Peirson, S.; Berson, D.; Brown, T.; Cooper, H.; Czeisler, C.; Figueiro, M.; Gamlin, P.; Lockley, S.; O’Hagan, J.; et al. Measuring and using light in the melanopsin age. Trends Neurosci. 2013, 37. [CrossRef] [PubMed]

53. Figueiro, M.G.; Bierman, A.; Plitnick, B.; Rea, M.S. Preliminary evidence that both blue and red light can induce alertness at night. BMC Neurosci. 2009, 10, 105. [CrossRef]

54. Plitnick, B.; Figueiro, M.; Wood, B.; Rea, M. The effects of red and blue light on alertness and mood at night. Light. Res. Technol. 2010, 42, 449-458. [CrossRef]

55. Wardono, P.; Hibino, H.; Koyama, S. Effects of Interior Colors, Lighting and Decors on Perceived Sociability, Emotion and Behavior Related to Social Dining. Procedia-Soc. Behav. Sci. 2012, 38, 362-372. [CrossRef]

56. aan het Rot, M.; Moskowitz, D.; Young, S. Exposure to bright light is associated with positive social interaction and good mood over short time periods: A naturalistic study in mildly seasonal people. J. Psychiatr. Res. 2008, 42, 311-319. [CrossRef]

57. Koval, I.V.; Bystryantseva, N.V.; Kolgushkina, S.V.; Lekus, E.U. Identification of a tool for evaluation of lighting solutions by users on the example of architectural lighting. In IOP Conference Series: Materials Science and Engineering; IOP Publishing Ltd.: Bristol, UK, 2020; Volume 944, p. 012018. [CrossRef]

58. Viikari, M.; Puolakka, M.; Halonen, L.; Rantakallio, A. Road lighting in change: User advice for designers. Light. Res. Technol. 2012, 44, 171-185. [CrossRef]

59. Bozorg Chenani, S.; Maksimainen, M.; Tetri, E.; Kosonen, I.; Luttinen, T. The effects of dimmable road lighting: A comparison of measured and perceived visibility. Transp. Res. Part F Traffic Psychol. Behav. 2016, 43, 141-156. [CrossRef]

60. Eloholma, M.; Ketomäki, J.; Orreveteläinen, P.; Halonen, L. Visual performance in night-time driving conditions. Ophthalmic Physiol. Opt. 2006, 26, 254-263. [CrossRef]

61. Wolska, A.; Sawicki, D. Evaluation of discomfort glare in the 50+ elderly: Experimental study. Int. J. Occup. Med. Environ. Health 2014, 27, 444-459. [CrossRef]

62. Jianyou, Y.; Shuya, S.; Xiaocong, W.; Zhizhong, L.; Jianbo, W.; Yanxin, C.; Shengshen, G. Simulation and Analysis of glare effect of two lane tunnel lighting under symmetrical lighting arrangement. In IOP Conference Series: Earth and Environmental Science; IOP Publishing Ltd: Bristol, UK, 2021; Volume 636, p. 012003. [CrossRef]

63. CIE. ILV: International Lighting Vocabulary, 2nd ed.; CIE S 017/E. CIE: Hong Kong, China, 2020.

64. Giovannini, L.; Favoino, F.; Lo Verso, V.R.M.; Serra, V.; Pellegrino, A. GLANCE (GLare ANnual Classes Evaluation): An approach for a simplified spatial glare evaluation. Build. Environ. 2020, 186, 107375. [CrossRef]

65. Hamedani, Z.; Solgi, E.; Hine, T.; Skates, H.; Isoardi, G.; Fernando, R. Lighting for work: A study of the relationships among discomfort glare, physiological responses and visual performance. Build. Environ. 2020, 167, 106478. [CrossRef]

66. Hamedani, M.; Dulley, B.; Murdoch, I. Glaucoma and glare. Eye 2020. [CrossRef]

67. Clear, R. Discomfort glare: What do we actually know? Light. Res. Technol. 2013, 45, 141-158. [CrossRef]

68. Akashi, Y.; Muramatsu, R.; Kanaya, S. Unified Glare Rating (UGR) and subjective appraisal of discomfort glare. Int. J. Light. Res. Technol. 1996, 28, 199-206. [CrossRef] 
69. Bullough, J.; Brons, J.; Qi, R.; Rea, M. Predicting discomfort glare from outdoor lighting installations. Light. Res. Technol. 2008, 40, 225-242. [CrossRef]

70. Żagan, W.; Zalewski, S.; Słomiński, S.; Kubiak, K. Methods for designing and simulating optical systems for luminaires. Bull. Pol. Acad. Sci. Tech. Sci. 2020, 68. [CrossRef]

71. Sammarco, J.J.; Mayton, A.G.; Rubinstein, E.N. LED Area Lighting to Reduce Glare for Roof Bolter Operators. Mining, Metall. Explor. 2020, 1-10. [CrossRef]

72. Zielinska-Dabkowska, K.M.; Xavia, K. Global Approaches to Reduce Light Pollution from Media Architecture and Non-Static, Self-Luminous LED Displays for Mixed-Use Urban Developments. Sustainability 2019, 11, 3446. [CrossRef]

73. Shepherd, A.J. Visual stimuli, light and lighting are common triggers of migraine and headache. J. Light Vis. Environ. 2010, 34, 94-100. [CrossRef]

74. Astanei, D.; Munteanu, F.; Nemes, C.; Ciobanu, A.; Ionescu, M.; Adochitei, M. Light flicker detection using high-speed imaging. In Proceedings of the 2017 International Conference on Modern Power Systems (MPS), Cluj-Napoca, Romania, 6-9 June 2017; pp. 1-4. [CrossRef]

75. Davis, J.; Hsieh, Y.H.; Lee, H.C. Humans perceive flicker artifacts at $500 \mathrm{~Hz}$. Sci. Rep. 2015, 5, 7861. [CrossRef]

76. Wilkins, A.; Veitch, J.; Lehman, B. LED lighting flicker and potential health concerns: IEEE standard PAR1789 update. In Proceedings of the 2010 IEEE Energy Conversion Congress and Exposition, Atlanta, GA, USA, 12-16 September 2010; pp. 171-178. [CrossRef]

77. Niemeyer, J.E. Viruses and circadian rhythms. Lab Anim. 2017, 46, 7. [CrossRef]

78. Hower, I.M.; Harper, S.A.; Buford, T.W. Circadian rhythms, exercise, and cardiovascular health. J. Circadian Rhythm. 2018, 16. [CrossRef]

79. Edgar, R.S.; Stangherlin, A.; Nagy, A.D.; Nicoll, M.P.; Efstathiou, S.; O'Neill, J.S.; Reddy, A.B. Cell autonomous regulation of herpes and influenza virus infection by the circadian clock. Proc. Natl. Acad. Sci. USA 2016, 113, 10085-10090. [CrossRef]

80. Wyse, C.A.; Selman, C.; Page, M.; Coogan, A.; Hazlerigg, D. Circadian desynchrony and metabolic dysfunction; did light pollution make us fat? Med. Hypotheses 2011, 77, 1139-1144. [CrossRef]

81. Stevens, R.G.; Brainard, G.C.; Blask, D.E.; Lockley, S.W.; Motta, M.E. Adverse Health Effects of Nighttime Lighting: Comments on American Medical Association Policy Statement. Am. J. Prev. Med. 2013, 45, 343-346. [CrossRef]

82. Dolsen, M.R.; Wyatt, J.K.; Harvey, A.G. Sleep, circadian rhythms, and risk across health domains in adolescents with an evening circadian preference. J. Clin. Child Adolesc. Psychol. 2019, 48, 480-490. [CrossRef] [PubMed]

83. Carrier, J. The role of sleep and circadian rhythms in health: A snapshot of key research interrogations. Pathol. Biol. (Paris) 2014, 62, 231-232. [CrossRef]

84. Khaper, N.; Bailey, C.D.; Ghugre, N.R.; Reitz, C.; Awosanmi, Z.; Waines, R.; Martino, T.A. Implications of disturbances in circadian rhythms for cardiovascular health: A new frontier in free radical biology. Free Radic. Biol. Med. 2018, 119, 85-92. [CrossRef]

85. Konturek, P.; Brzozowski, T.; Konturek, S. Gut clock: Implication of circadian rhythms in the gastrointestinal tract. J. Physiol. Pharmacol. 2011, 62, 139.

86. Varcoe, T.J. Timing is everything: Maternal circadian rhythms and the developmental origins of health and disease. J. Physiol. 2018, 596, 5493. [CrossRef]

87. Jagannath, A.; Taylor, L.; Wakaf, Z.; Vasudevan, S.R.; Foster, R.G. The genetics of circadian rhythms, sleep and health. Hum. Mol. Genet. 2017, 26, R128-R138. [CrossRef]

88. Ray, S.; Reddy, A.B. COVID-19 management in light of the circadian clock. Nat. Rev. Mol. Cell Biol. 2020, 21, 494-495. [CrossRef] [PubMed]

89. Silva, F.R.D.; Guerreiro, R.D.C.; Andrade, H.D.A.; Stieler, E.; Silva, A.; de Mello, M.T. Does the compromised sleep and circadian disruption of night and shiftworkers make them highly vulnerable to 2019 coronavirus disease (COVID-19)? Chronobiol. Int. 2020, 37, 607-617. [CrossRef]

90. Brown, G.M. Light, melatonin and the sleep-wake cycle. J. Psychiatry Neurosci. 1994, 19, 345.

91. Lockley, S. Circadian Rhythms: Influence of Light in Humans; Elsevier: Amsterdam, The Netherlands, 2009; Volume 2, pp. 971-988. [CrossRef]

92. Esposito, E.; Cuzzocrea, S. Antiinflammatory activity of melatonin in central nervous system. Curr. Neuropharmacol. 2010, 8, 228-242. [CrossRef]

93. Phillips, A.J.; Vidafar, P.; Burns, A.C.; McGlashan, E.M.; Anderson, C.; Rajaratnam, S.M.; Lockley, S.W.; Cain, S.W. High sensitivity and interindividual variability in the response of the human circadian system to evening light. Proc. Natl. Acad. Sci. USA 2019, 116, 12019-12024. [CrossRef] [PubMed]

94. Brainard, G.C.; Hanifin, J.P.; Greeson, J.M.; Byrne, B.; Glickman, G.; Gerner, E.; Rollag, M.D. Action Spectrum for Melatonin Regulation in Humans: Evidence for a Novel Circadian Photoreceptor. J. Neurosci. 2001, 21, 6405-6412. [CrossRef] [PubMed]

95. Moore-Ede, M.; Heitmann, A.; Guttkuhn, R. Circadian potency spectrum with extended exposure to polychromatic white LED Light under workplace conditions. J. Biol. Rhythm. 2020, 35, 405-415. [CrossRef] [PubMed]

96. Burgess, H.J.; Savic, N.; Sletten, T.; Roach, G.; Gilbert, S.S.; Dawson, D. The relationship between the dim light melatonin onset and sleep on a regular schedule in young healthy adults. Behav. Sleep Med. 2003, 1, 102-114. [CrossRef] [PubMed]

97. Cajochen, C. Alerting effects of light. Sleep Med. Rev. 2007, 11, 453-464. [CrossRef] 
98. Peña-García, A.; Sędziwy, A. Optimizing lighting of rural roads and protected areas with white light: A compromise among light pollution, energy savings, and visibility. Leukos 2020, 16, 147-156. [CrossRef]

99. Wang, R.; Zhai, X. Handbook of Energy Systems in Green Buildings; Springer: Berlin, Germany, 2018; Volume 160.

100. Farrington, D.P.; Welsh, B.C. Improved street lighting and crime prevention. Justice Q. 2002, 19, 313-342. [CrossRef]

101. Chalfin, A.; Hansen, B.; Lerner, J.; Parker, L. Reducing Crime through Environmental Design: Evidence from a Randomized Experiment of Street Lighting in New York City. Working Paper 25798, 2019. [CrossRef]

102. Arvate, P.; Falsete, F.O.; Ribeiro, F.G.; Souza, A.P. Lighting and homicides: Evaluating the effect of an electrification policy in rural Brazil on violent crime reduction. J. Quant. Criminol. 2018, 34, 1047-1078. [CrossRef]

103. World Health Organization. Global Status Report on Road Safety 2018; Licence: CC BYNC-SA 3.0 IGO; World Health Organization: Geneva, Switzerland, 2018.

104. CIE. Road Lighting as an Accident Countermeasure; CIE 093; CIE: Hong Kong, China, 1992.

105. Jackett, M.; Frith, W. Quantifying the impact of road lighting on road safety-A New Zealand Study. IATSS Res. 2013, 36, 139-145. [CrossRef]

106. Beyer, F.R.; Ker, K. Street lighting for preventing road traffic injuries. Cochrane Database Syst. Rev. 2009. [CrossRef]

107. Bhagavathula, R.; Gibbons, R.B.; Edwards, C.J. Relationship between Roadway Illuminance Level and Nighttime Rural Intersection Safety. Transp. Res. Rec. 2015, 2485, 8-15. [CrossRef]

108. Easa, S.M.; Reed, M.J.; Russo, F.; Dabbour, E.; Mehmood, A.; Curtis, K. Effect of Increasing Road Light Luminance on Night Driving Performance of Older Adults. Int. J. Eng. Appl. Sci. 2010, 6, 41-48. [CrossRef]

109. Reed, M.; Easa, S.M. Effect of luminance on night driving performance of younger-old and older-old adults. Int. J. Res. Rev. Appl. Sci. 2011, 7, 218-227.

110. Ndjiongue, A.R.; Ferreira, H.C. An overview of outdoor visible light communications. Trans. Emerg. Telecommun. Technol. 2018, 29, e3448. [CrossRef]

111. Kumar, N.; Terra, D.; Lourenço, N.; Nero Alves, L.; Aguiar, R.L. Visible light communication for intelligent transportation in road safety applications. In Proceedings of the 2011 7th International Wireless Communications and Mobile Computing Conference, Istanbul, Turkey, 4-8 July 2011; pp. 1513-1518. [CrossRef]

112. World Health Organization; FIA Foundation for the Automobile and Society; Global Road Safety Partnership and World Bank. Pedestrian Safety: A Road Safety Manual for Decision-Makers and Practitioners; World Health Organization: Geneva, Switzerland, 2013; p. xvi. 114p.

113. Uttley, J.; Fotios, S. The effect of ambient light condition on road traffic collisions involving pedestrians on pedestrian crossings. Accid. Anal. Prev. 2017, 108, 189-200. [CrossRef] [PubMed]

114. Siddiqui, N.A.; Chu, X.; Guttenplan, M. Crossing Locations, Light Conditions, and Pedestrian Injury Severity. Transp. Res. Rec. 2006, 1982, 141-149. [CrossRef]

115. Maynard, W.S. Prevention through Design-Slips, Trips and Falls. Paper presented at the Professional Development Conference and Exposition, Las Vegas, NV, USA, June 2013. Available online: https:/ / onepetro.org/ASSPPDCE/proceedings-abstract/ ASSE13 / All-ASSE13/ASSE-13-717/77496 (accessed on 30 June 2013).

116. Black, A.; Wood, J. Vision and falls. Clin. Exp. Optom. 2005, 88, 212-222. [CrossRef]

117. Fotios, S.; Uttley, J. Illuminance required to detect a pavement obstacle of critical size. Light. Res. Technol. 2018, 50, 390-404. [CrossRef]

118. Fotios, S.; Mao, Y.; Uttley, J.; Cheal, C. Road lighting for pedestrians: Effects of luminaire position on the detection of raised and lowered trip hazards. Light. Res. Technol. 2020, 52, 79-93. [CrossRef]

119. Cheng, T.J.; Yang, B.; Holloway, C.; Tyler, N. Effect of environmental factors on how older pedestrians detect an upcoming step. Light. Res. Technol. 2018, 50, 405-415. [CrossRef]

120. United Nations; Department of Economic and Social Affairs; Population Division. World Population Ageing: 2017 Highlights; 2017. ISBN 9789211515510. Available online: https://www.un.org/en/development/desa/population/publications/pdf/ageing/ WPA2017_Highlights.pdf (accessed on 30 December 2017).

121. Van der Pols, J.; Bates, C.; McGraw, P.; Thompson, J.; Reacher, M.; Prentice, A.; Finch, S. Visual acuity measurements in a national sample of British elderly people. Br. J. Ophthalmol. 2000, 84, 165-170. [CrossRef] [PubMed]

122. Dalke, H.; Little, J.; Niemann, E.; Camgoz, N.; Steadman, G.; Hill, S.; Stott, L. Colour and lighting in hospital design. Opt. Laser Technol. 2006, 38, 343-365. [CrossRef]

123. van den Berg, T.J.; van Rijn, L.; Kaper-Bongers, R.; Vonhoff, D.; Völker-Dieben, H.; Grabner, G.; Nischler, C.; Emesz, M.; Wilhelm, H.; Gamer, D.; et al. Disability Glare in the Aging Eye. Assessment and Impact on Driving. J. Optom. 2009, 2, 112-118. [CrossRef]

124. Shikder, S.; Mourshed, M.; Price, A. Therapeutic lighting design for the elderly: A review. Perspect. Public Health 2012, 132, 282-291. [CrossRef]

125. Yamagishi, M.; Yamaba, K.; Kubo, C.; Nokura, K.; Nagata, M. Effects of LED lighting characteristics on visual performance of elderly people. Gerontechnology 2008, 7, 243. [CrossRef]

126. Rall, E.; Hansen, R.; Pauleit, S. The added value of public participation GIS (PPGIS) for urban green infrastructure planning. Urban For. Urban Green. 2019, 40, 264-274. [CrossRef] 
127. Zissis, G., Energy Consumption and Environmental and Economic Impact of Lighting: The Current Situation. In Handbook of Advanced Lighting Technology; Karlicek, R., Sun, C.C., Zissis, G., Ma, R., Eds.; Springer International Publishing: Cham, Switzerland, 2016; pp. 1-13. [CrossRef]

128. Yoomak, S.; Jettanasen, C.; Ngaopitakkul, A.; Bunjongjit, S.; Leelajindakrairerk, M. Comparative study of lighting quality and power quality for LED and HPS luminaires in a roadway lighting system. Energy Build. 2018, 159, 542-557. [CrossRef]

129. Pattison, M.; Hansen, M.; Bardsley, N.; Elliott, C.; Lee, K.; Pattison, L.; Tsao, J. 2019 Lighting RED Opportunities; Technical report; US Department of Energy: Washington, DC, USA, 2020. [CrossRef]

130. Azevedo, I.L.; Morgan, M.G.; Morgan, F. The transition to solid-state lighting. Proc. IEEE 2009, 97, 481-510. [CrossRef]

131. Wang, Y.; Alonso, J.M.; Ruan, X. A Review of LED Drivers and Related Technologies. IEEE Trans. Ind. Electron. 2017, 64, 5754-5765. [CrossRef]

132. Lasance, C.J.; Poppe, A. Thermal Management for LED Applications; Solid State Lighting Technology and Application Series; Springer Science Business Media: New York, NY, USA, 2014; Volume 2. [CrossRef]

133. ur Rahman, T.; Raza, S.; Saeed, M.; Jameel, S. An Emerging White LED Technology and associated Thermal Issues-A Review. J. Appl. Emerg. Sci. 2019, 9, 106-120. [CrossRef]

134. Ma, H.K.; Hsieh, C.H.; Liao, S.K. Study of an innovative multiple fan system with one piezoelectric actuator embedded in a circular heat sink. In Proceedings of the 2017 33rd Thermal Measurement, Modeling Management Symposium (SEMI-THERM), San Jose, CA, USA, 13-17 March 2017; pp. 6-12. [CrossRef]

135. Chen, W.; Fan, J.; Qi, G.; Sun, C.; Yang, W.; Cao, S. Optical and Thermal Designs of LED Matrix Module used in Automotive Headlamps. In Proceedings of the 2019 16th China International Forum on Solid State Lighting \& 2019 International Forum on Wide Bandgap Semiconductors China (SSLChina: IFWS), Shenzhen, China, 25-27 November 2019; pp. $220-224$.

136. Chang, H.; Pao, C. Flip Light Emitting Diode Chip and Method of Fabricating the Same. US Patent 8,735,189, 27 May 2014.

137. Penning, J.; Stober, K.; Taylor, V.; Yamada, M. Energy Savings Forecast of Solid-State Lighting in General Illumination Applications; Technical report; U.S. Department of Energy: Washington, DC, USA, 2016. [CrossRef]

138. Kostic, A.; Kremic, M.; Djokic, L.; Kostic, M. Light-emitting diodes in street and roadway lighting-A case study involving mesopic effects. Light. Res. Technol. 2013, 45, 217-229. [CrossRef]

139. Juntunen, E.; Sarjanoja, E.M.; Eskeli, J.; Pihlajaniemi, H.; Österlund, T. Smart and dynamic route lighting control based on movement tracking. Build. Environ. 2018, 142, 472-483. [CrossRef]

140. Sánchez Sutil, F.; Cano-Ortega, A. Smart public lighting control and measurement system using LoRa network. Electronics 2020, 9, 124. [CrossRef]

141. Brown, G.; Kyttä, M. Key issues and research priorities for public participation GIS (PPGIS): A synthesis based on empirical research. Appl. Geogr. 2014, 46, 122-136. [CrossRef]

142. Martirano, L. A smart lighting control to save energy. In Proceedings of the 6th IEEE International Conference on Intelligent Data Acquisition and Advanced Computing Systems, Prague, Czech Republic, 15-17 September 2011; Volume 1, pp. 132-138. [CrossRef]

143. Pandharipande, A.; Newsham, G.R. Lighting controls: Evolution and revolution. Light. Res. Technol. 2018, 50, 115-128. [CrossRef]

144. Pracki, P.; Skarżyński, K. A Multi-Criteria Assessment Procedure for Outdoor Lighting at the Design Stage. Sustainability 2020, 12, 1330. [CrossRef]

145. Petritoli, E.; Leccese, F.; Pizzuti, S.; Pieroni, F. Smart lighting as basic building block of smart city: An energy performance comparative case study. Measurement 2019, 136, 466-477. [CrossRef]

146. Hegedüs, J.; Hantos, G.; Poppe, A. Embedded multi-domain LED model for adaptive dimming of streetlighting luminaires. In Proceedings of the 2016 22nd International Workshop on Thermal Investigations of ICs and Systems (THERMINIC), Budapest, Hungary, 21-23 September 2016; pp. 208-212. [CrossRef]

147. Lau, S.P.; Merrett, G.V.; Weddell, A.S.; White, N.M. A traffic-aware street lighting scheme for Smart Cities using autonomous networked sensors. Comput. Electr. Eng. 2015, 45, 192-207. [CrossRef]

148. Carli, R.; Dotoli, M. A dynamic programming approach for the decentralized control of energy retrofit in large-scale street lighting systems. IEEE Trans. Autom. Sci. Eng. 2020, 17, 1140-1157. [CrossRef]

149. Dai, Q.; Shan, Q.; Lam, H.; Hao, L.; Lin, Y.; Cui, Z. Circadian-effect engineering of solid-state lighting spectra for beneficial and tunable lighting. Opt. Express 2016, 24, 20049-20059. [CrossRef]

150. Ellis, E.; Gonzalez, E.; Kratzer, D.; McEachron, D.; Yeutter, G. Auto-tuning Daylight with LEDs: Sustainable Lighting for Health and Wellbeing. ARCC Conf. Repos. 2014. [CrossRef]

151. Tingzhu, W.; Lu, Y.; Guo, Z.; Zheng, L.; Zhu, H.; Xiao, Y.; Shih, T.M.; Lin, Y.; Chen, Z. Improvements of mesopic luminance for light-emitting-diode-based outdoor light sources via tuning scotopic/photopic ratios. Opt. Express 2017, 25, $4887-4897$. [CrossRef]

152. Matheus, L.E.M.; Vieira, A.B.; Vieira, L.F.; Vieira, M.A.; Gnawali, O. Visible light communication: Concepts, applications and challenges. IEEE Commun. Surv. Tutor. 2019, 21, 3204-3237. [CrossRef]

153. Garratt, M.J.; Jenkins, S.R.; Davies, T.W. Mapping the consequences of artificial light at night for intertidal ecosystems. Sci. Total. Environ. 2019, 691, 760-768. [CrossRef] [PubMed]

154. Bierman, A. Will switching to LED outdoor lighting increase sky glow? Light. Res. Technol. 2012, 44, 449-458. [CrossRef] 
155. CIE. Guide on the Limitation of the Effects of Obtrusive Light from Outdoor Lighting Installations; Second Edition: CIE 150; CIE: Hong Kong, China, 2017.

156. Bennie, J.; Duffy, J.P.; Davies, T.W.; Correa-Cano, M.E.; Gaston, K.J. Global trends in exposure to light pollution in natural terrestrial ecosystems. Remote Sens. 2015, 7, 2715-2730. [CrossRef]

157. Jechow, A.; Kolláth, Z.; Lerner, A.; Hänel, A.; Shashar, N.; Hölker, F.; Kyba, C. Measuring light pollution with fisheye lens imagery from a moving boat, a proof of concept. arXiv 2017, arXiv:1703.08484. 19, 15-25.

158. Tabaka, P. Pilot Measurement of Illuminance in the Context of Light Pollution Performed with an Unmanned Aerial Vehicle. Remote Sens. 2020, 12, 2124. [CrossRef]

159. Bouroussis, C.A.; Topalis, F.V. Assessment of outdoor lighting installations and their impact on light pollution using unmanned aircraft systems-The concept of the drone-gonio-photometer. J. Quant. Spectrosc. Radiat. Transf. 2020, 253, 107155. [CrossRef]

160. Levin, N.; Kyba, C.C.; Zhang, Q.; Sánchez de Miguel, A.; Román, M.O.; Li, X.; Portnov, B.A.; Molthan, A.L.; Jechow, A.; Miller, S.D.; et al. Remote sensing of night lights: A review and an outlook for the future. Remote Sens. Environ. 2020, $237,111443$. [CrossRef]

161. Kinzey, B.R.; Perrin, T.E.; Miller, N.J.; Kocifaj, M.; Aube, M.; Lamphar, H.A. An Investigation of LED Street Lighting's Impact on Sky Glow; Technical report; Pacific Northwest National Lab (PNNL): Richland, WA, USA, 2017. [CrossRef]

162. Katz, Y.; Levin, N. Quantifying urban light pollution-A comparison between field measurements and EROS-B imagery. Remote Sens. Environ. 2016, 177, 65-77. [CrossRef]

163. Simons, A.L.; Yin, X.; Longcore, T. High correlation but high scale-dependent variance between satellite measured night lights and terrestrial exposure. Environ. Res. Commun. 2020, 2, 021006. [CrossRef]

164. Kocifaj, M.; Wallner, S.; Solano-Lamphar, H.A. An asymptotic formula for skyglow modelling over a large territory. Mon. Not. R. Astron. Soc. 2019, 485, 2214-2224. [CrossRef]

165. Aubé, M.; Simoneau, A.; Muñoz-Tuñón, C.; Díaz-Castro, J.; Serra-Ricart, M. Restoring the night sky darkness at Observatorio del Teide: First application of the model Illumina version 2. Mon. Not. R. Astron. Soc. 2020, 497, 2501-2516. [CrossRef]

166. Duriscoe, D.M. Measuring anthropogenic sky glow using a natural sky brightness model. Publ. Astron. Soc. Pac. 2013, 125, 1370. [CrossRef]

167. Mouritsen, H.; Larsen, O.N. Migrating songbirds tested in computer-controlled Emlen funnels use stellar cues for a timeindependent compass. J. Exp. Biol. 2001, 204, 3855-3865. [CrossRef]

168. Dacke, M.; Baird, E.; Byrne, M.; Scholtz, C.H.; Warrant, E.J. Dung beetles use the Milky Way for orientation. Curr. Biol. 2013, 23, 298-300. [CrossRef]

169. CIE. Guidelines for Minimizing Urban Sky Glow Near Astronomical Observatories: CIE 001; CIE: Hong Kong, China, 1980.

170. Sutherland, W.J.; Bardsley, S.; Bennun, L.; Clout, M.; Côté, I.M.; Depledge, M.H.; Dicks, L.V.; Dobson, A.P.; Fellman, L.; Fleishman, E.; et al. Horizon scan of global conservation issues for 2011. Trends Ecol. Evol. 2011, 26, 10-16. [CrossRef]

171. Mitchell, D.; Gallaway, T. Dark sky tourism: Economic impacts on the Colorado Plateau Economy, USA. Tour. Rev. 2019, 74, 930-942. [CrossRef]

172. Mauck, B.; Gläser, N.; Schlosser, W.; Dehnhardt, G. Harbour seals (Phoca vitulina) can steer by the stars. Anim. Cogn. 2008, 11, 715-718. [CrossRef] [PubMed]

173. FAO. The State of World Fisheries and Aquaculture 2020. In Sustainability in Action; FAO: Rome, Italy, 2020. [CrossRef]

174. Stanford, L.L.; Spacie, A. Biological Monitoring of Aquatic Systems; CRC Press: Boca Raton, FL, USA, 1994.

175. Mcleod, E.; Chmura, G.L.; Bouillon, S.; Salm, R.; Björk, M.; Duarte, C.M.; Lovelock, C.E.; Schlesinger, W.H.; Silliman, B.R. A blueprint for blue carbon: Toward an improved understanding of the role of vegetated coastal habitats in sequestering $\mathrm{CO}_{2}$. Front. Ecol. Environ. 2011, 9, 552-560. [CrossRef]

176. Gruber, N.; Clement, D.; Carter, B.R.; Feely, R.A.; van Heuven, S.; Hoppema, M.; Ishii, M.; Key, R.M.; Kozyr, A.; Lauvset, S.K.; et al. The oceanic sink for anthropogenic $\mathrm{CO}_{2}$ from 1994 to 2007. Science 2019, 363, 1193-1199. [CrossRef] [PubMed]

177. Edgar, R.; Green, E.; Zhao, Y.; van Ooijen, G.; Olmedo, M.; Qin, X.; Xu, Y.; Pan, M.; Valekunja, U.; Feeney, K.; et al. Peroxiredoxins are conserved markers of circadian rhythms. Nature 2012, 485, 459-464. [CrossRef]

178. Dvornyk, V.; Vinogradova, O.; Nevo, E. Origin and evolution of circadian clock genes in prokaryotes. Proc. Natl. Acad. Sci. USA 2003, 100, 2495-2500. [CrossRef]

179. Davies, T.W.; Duffy, J.P.; Bennie, J.; Gaston, K.J. The nature, extent, and ecological implications of marine light pollution. Front. Ecol. Environ. 2014, 12, 347-355. [CrossRef]

180. Cohen, J.H.; B, F.R. Zooplankton diel vertical migration-A review of proximate control. Oceanogr. Mar. Biol. 2009, 47, 77-110.

181. Witman, S. World's biggest oxygen producers living in swirling ocean waters. J. Geophys. Res. Ocean. 2017. [CrossRef]

182. Tamir, R.; Eyal, G.; Cohen, I.; Loya, Y. Effects of light pollution on the early life stages of the most abundant northern red sea coral. Microorganisms 2020, 8, 193. [CrossRef]

183. Becker, A.; Whitfield, A.K.; Cowley, P.D.; Järnegren, J.; Næsje, T.F. Potential effects of artificial light associated with anthropogenic infrastructure on the abundance and foraging behaviour of estuary-associated fishes. J. Appl. Ecol. 2013, 50, 43-50. [CrossRef]

184. Dwyer, R.G.; Bearhop, S.; Campbell, H.A.; Bryant, D.M. Shedding light on light: Benefits of anthropogenic illumination to a nocturnally foraging shorebird. J. Anim. Ecol. 2013, 82, 478-485. [CrossRef]

185. Delhey, K.; Peters, A. Conservation implications of anthropogenic impacts on visual communication and camouflage. Conserv. Biol. 2017, 31, 30-39. [CrossRef] 
186. Maggi, E.; Bongiorni, L.; Fontanini, D.; Capocchi, A.; Dal Bello, M.; Giacomelli, A.; Benedetti-Cecchi, L. Artificial light at night erases positive interactions across trophic levels. Funct. Ecol. 2020, 34, 694-706. [CrossRef]

187. Davies, T.W.; McKee, D.; Fishwick, J.; Tidau, S.; Smyth, T. Biologically important artificial light at night on the seafloor. Sci. Rep. 2020, 10, 12545. [CrossRef]

188. Small, C.; Nicholls, R.J. A global analysis of human settlement in coastal zones. J. Coast. Res. 2003, 19, 584-599.

189. Onorati, M.; Vignoli, L. The darker the night, the brighter the stars: Consequences of nocturnal brightness on amphibian reproduction. Biol. J. Linn. Soc. 2017, 120, 961-976. [CrossRef]

190. Dananay, K.L.; Benard, M.F. Artificial light at night decreases metamorphic duration and juvenile growth in a widespread amphibian. Proc. R. Soc. B Biol. Sci. 2018, 285, 20180367. [CrossRef] [PubMed]

191. Thawley, C.J.; Kolbe, J.J. Artificial light at night increases growth and reproductive output in Anolis lizards. Proc. R. Soc. B Biol. Sci. 2020, 287, 20191682. [CrossRef]

192. Swindall, J.E.; Ober, H.K.; Lamont, M.M.; Carthy, R.R. Informing sea turtle outreach efforts to maximize effectiveness. Wildl. Soc. Bull. 2019, 43, 436-446. [CrossRef]

193. Perry, G.; Buchanan, B.W.; Fisher, R.N.; Salmon, M.; Wise, S.E. Effects of artificial night lighting on amphibians and reptiles in urban environments. Urban Herpetol. 2008, 3, 239-256.

194. Patrício-Roberto, G.B.; Campos, M.J.O. Aspects of Landscape and Pollinators-What is Important to Bee Conservation? Diversity 2014, 6, 158-175. [CrossRef]

195. Goulson, D.; Lye, G.; Darvill, B. Decline and Conservation of Bumble Bees. Annu. Rev. Entomol. 2008, 53, 191-208. [CrossRef]

196. Macgregor, C.J.; Pocock, M.J.; Fox, R.; Evans, D.M. Pollination by nocturnal L epidoptera, and the effects of light pollution: A review. Ecol. Entomol. 2015, 40, 187-198. [CrossRef]

197. Grubisic, M.; van Grunsven, R.; Kyba, C.; Manfrin, A.; Hölker, F. Insect declines and agroecosystems: Does light pollution matter? Ann. Appl. Biol. 2018, 173, 180-189. [CrossRef]

198. Owens, A.C.; Cochard, P.; Durrant, J.; Farnworth, B.; Perkin, E.K.; Seymoure, B. Light pollution is a driver of insect declines. Biol. Conserv. 2020, 241, 108259. [CrossRef]

199. Schumann, K.; Wittig, R.; Thiombiano, A.; Becker, U.; Hahn, K. Impact of land-use type and harvesting on population structure of a non-timber forest product-providing tree in a semi-arid savanna, West Africa. Biol. Conserv. 2011, 144, 2369-2376. [CrossRef]

200. Grenis, K.; Murphy, S.M. Direct and indirect effects of light pollution on the performance of an herbivorous insect. Insect Sci. 2019, 26, 770-776. [CrossRef]

201. Minnaar, C.; Boyles, J.G.; Minnaar, I.A.; Sole, C.L.; McKechnie, A.E. Stacking the odds: Light pollution may shift the balance in an ancient predator-prey arms race. J. Appl. Ecol. 2015, 52, 522-531. [CrossRef]

202. Elgert, C.; Hopkins, J.; Kaitala, A.; Candolin, U. Reproduction under light pollution: Maladaptive response to spatial variation in artificial light in a glow-worm. Proc. R. Soc. B 2020, 287, 20200806. [CrossRef] [PubMed]

203. Underwood, C.N.; Davies, T.W.; Queirós, A.M. Artificial light at night alters trophic interactions of intertidal invertebrates. J. Anim. Ecol. 2017, 86, 781-789. [CrossRef]

204. Boom, M.P.; Spoelstra, K.; Biere, A.; Knop, E.; Visser, M.E. Pollination and fruit infestation under artificial light at night: Light colour matters. Sci. Rep. 2020, 10, 1-6.

205. Gaston, K.J.; Bennie, J.; Davies, T.W.; Hopkins, J. The ecological impacts of nighttime light pollution: A mechanistic appraisal. Biol. Rev. 2013, 88, 912-927. [CrossRef] [PubMed]

206. Singhal, R.; Kumar, M.; Bose, B. Ecophysiological responses of artificial night light pollution in plants. Russ. J. Plant Physiol. 2019, 66, 190-202. [CrossRef]

207. Bennie, J.; Davies, T.W.; Cruse, D.; Gaston, K.J. Ecological effects of artificial light at night on wild plants. J. Ecol. 2016, 104, 611-620. [CrossRef]

208. Škvareninová, J.; Tuhárska, M.; Škvarenina, J.; Babálová, D.; Slobodníková, L.; Slobodník, B.; Stř̌edová, H.; Mind'aš, J. Effects of light pollution on tree phenology in the urban environment. Morav. Geogr. Rep. 2017, 25, 282-290. [CrossRef]

209. Blümel, M.; Dally, N.; Jung, C. Flowering time regulation in crops-What did we learn from Arabidopsis? Curr. Opin. Biotechnol. 2015, 32, 121-129. [CrossRef] [PubMed]

210. Higuchi, Y. Florigen and anti-florigen: Flowering regulation in horticultural crops. Breed. Sci. 2018, 68, 109-118. [CrossRef]

211. Raven, J.; Cockell, C. Influence on Photosynthesis of Starlight, Moonlight, Planetlight, and Light Pollution (Reflections on Photosynthetically Active Radiation in the Universe). Astrobiology 2006, 6, 668-675. [CrossRef]

212. ChiLing, C.; YunHam, S.; ChiaJen, L.; YahnChir, L. Effect of night illumination on growth and yield of soybean. J. Taiwan Agric. Res. 2009, 58, 146-154.

213. Reuter, D.N.; Stewart, C.N., Jr.; Lenaghan, S.C. Lighting the Way: Advances in Engineering Autoluminescent Plants. Trends Plant Sci. 2020, 25, 1176-1179. [CrossRef]

214. CEN. EN 13201-1-5 Standards for Road lighting all parts. In European Standards; CEN: Tokyo, Japan, 2014.

215. CEN. EN 12464-2:2014 Light and lighting. Lighting of work places-Outdoor work places. In European Standards; CEN: Tokyo, Japan, 2014.

216. CEN. EN 12193:2018 Light and lighting—Sports lighting. In European Standards; CEN: Tokyo, Japan, 2018.

217. CIE. Guide for Floodlighting; Cie 094; CIE: Hong Kong, China, 1993. 
218. Haddock, J.K.; Threlfall, C.G.; Law, B.; Hochuli, D.F. Light pollution at the urban forest edge negatively impacts insectivorous bats. Biol. Conserv. 2019, 236, 17-28. [CrossRef]

219. Barentine, J.C.; Kundracik, F.; Kocifaj, M.; Sanders, J.C.; Esquerdo, G.A.; Dalton, A.M.; Foott, B.; Grauer, A.; Tucker, S.; Kyba, C.C. Recovering the city street lighting fraction from skyglow measurements in a large-scale municipal dimming experiment. J. Quant. Spectrosc. Radiat. Transf. 2020, 253, 107120. [CrossRef]

220. Briscoe, A.D.; Chittka, L. The Evolution of Color Vision in Insects. Annu. Rev. Entomol. 2001, 46, 471-510. [CrossRef] [PubMed]

221. Alhassan, A.I.; Farrell, R.M.; Saifaddin, B.; Mughal, A.; Wu, F.; DenBaars, S.P.; Nakamura, S.; Speck, J.S. High luminous efficacy green light-emitting diodes with AlGaN cap layer. Opt. Express 2016, 24, 17868-17873. [CrossRef] [PubMed]

222. Wiltschko, R.; Stapput, K.; Bischof, H.J.; Wiltschko, W. Light-dependent magnetoreception in birds: Increasing intensity of monochromatic light changes the nature of the response. Front. Zool. 2007, 4, 5. [CrossRef] [PubMed]

223. Hoker, F.; Jechow, A.; Schroer, S.; Gessner, M.O. Nachtliches Licht und Lichtverschmutzung in und um Gewässer. In Handbuch Angewandte Limnologie: Grundlagen-Gewässerbelastung-Restaurierung-Aquatische Okotoxikologie-Bewertung-Gewässerschutz; Wiley Online Library: Hoboken, NJ, USA,2014; pp. 1-26.

224. Kyba, C.; Ruby, A.; Kuechly, H.; Kinzey, B.; Miller, N.; Sanders, J.; Barentine, J.; Kleinodt, R.; Espey, B. Direct measurement of the contribution of street lighting to satellite observations of nighttime light emissions from urban areas. Light. Res. Technol. 2020. [CrossRef]

225. Kuechly, H.U.; Kyba, C.C.; Ruhtz, T.; Lindemann, C.; Wolter, C.; Fischer, J.; Hölker, F. Aerial survey and spatial analysis of sources of light pollution in Berlin, Germany. Remote Sens. Environ. 2012, 126, 39-50. [CrossRef]

226. Zielińska-Dąbkowska, K.; Gen Schieck, A.F. Designing digital displays and interactive media in today's cities by night. Do we know enough about attracting attention to do so? In Conscious Cities Anthology 2018: Human-Centred Design, Science, and Technology; pp. 1-8. Available online: https://theccd.org/article/45/designing-digital-displays-and-interactive-media-in-todays-citiesby-night-do-we-know-enough-about-attracting-attention-to-do-so/ (accessed on 31 December 2018). [CrossRef]

227. Korõtko, T.; Rosin, A.; Varjas, T.; Ahmadiahangar, R. Awareness of BSR Municipalities about Sustainable Urban Lighting and Green Public Procurements. In Proceedings of the 2020 IEEE International Conference on Environment and Electrical Engineering and 2020 IEEE Industrial and Commercial Power Systems Europe (EEEIC/I\&CPS Europe), Madrid, Spain, 9-12 June 2020; pp. 1-6. 